\title{
Kamu Görevlilerinin Dernekler ve Vakıflar Bağlamında Örgütlenme Özgürlüğü: Anayasa Hukuku Perspektifinden Bir Değerlendirme
}

\author{
Ulaş Karan
}

Öz

Örgütlenme özgürlüğü, medeni, ekonomik ve siyasi amaçlarla ve farklı biçimlerde kullanılabilmektedir. Hakkın Türkiye'de en yaygın kullanıldığı biçimler ise dernekler ve vakıflardır. Örgütlenme özgürlüğünün öznesi herkes olsa da gerek uluslararası hukuk gerekse Türkiye Cumhuriyeti Anayasası özgürlüğün kullanılması bakımından kamu görevlileri için önemli kısıtlamaların yolunu açmıştır. Bu çalışmada karşılaştırmalı bir perspektifle uluslararası standartlar ışığında, özellikle Türk Silahlı Kuvvetleri, Emniyet Genel Müdürlüğü, Jandarma Genel Komutanlığı ve Sahil Güvenlik Komutanlığı mensupları ile yargı mensupları dışında kalan diğer kamu görevlilerinin örgütlenme özgürlüğü üzerinde durulmuştur. Bir makalede örgütlenme özgürlüğünün tüm boyutları üzerinde durulmasının mümkün olmaması dikkate alınarak konu yalnızca dernek ve vakıf kurucusu olma ve bunlara üyelikle sınırlı olarak incelenmiştir. Çalışma ile kamu görevlilerinin dernekler ve vakıflarda örgütlenmelerinin önündeki yasal engellerin tespit edilmesi ve bu engellerin ortadan kaldırılması için öneriler sunulması amaçlanmıştr.

\section{Anahtar Kelimeler \\ Anayasa • Örgütlenme özgürlüğü • Dernek • Vakıf • Kamu görevlileri}

\section{Civil Servants' Freedom of Association within the Context of Associations and Foundations: An Assessment from a Constitutional Law Perspective}

\begin{abstract}
Freedom of association is a right that can be used for civil, economic, and political purposes as well as in different in different forms. In Turkey, associations and foundations are the most commonly used forms. Although everyone has the right to freedom of association, international law as well as the Constitution of the Republic of Turkey include significant restrictions on public officials. This study focuses particularly on freedom of association for members of the Turkish Armed Forces, General Directorate of Police, General Command of Gendarmerie, the Turkish Coast Guard Command, and other public officials. Exceptions are members of the judiciary, based on international standards from a comparative perspective. Considering the impossibility of focusing on all dimensions of freedom of association in a short study, the issue has been examined only in the context of being a founders and members of associations and foundations. The aim of this study, then, is to identify the legal barriers to public officials' organizations and to provide recommendations for improvement.
\end{abstract}

\section{Keywords}

Constitution • Freedom of association • Association • Foundation • Civil servants

\footnotetext{
* Sorumlu Yazar: Ulaş Karan (Dr. Öğr. Üyesi), İstanbul Bilgi Üniversitesi, Hukuk Fakültesi, Anayasa Hukuku Anabilim Dalı, İstanbul, Türkiye: E-posta: ulas.karan@bilgi.edu.tr
}

Atıf: Karan Ulaş, “Kamu Görevlilerinin Dernekler ve Vakıflar Bağlamında Örgütlenme Özgürlüğü: Anayasa Hukuku Perspektifinden Bir Değerlendirme”, İstanbul Hukuk Mecmuası, 76/1, 2018, 65-108. 


\section{I. Örgüitlenme Özgürlüğüne Genel Bakış}

\section{A. Genel Olarak Örgüt Kavramı}

Demokrasi ile oldukça yakından ilişkili bir hak olan örgütlenme özgürlüğünün mevcudiyeti günümüzde bir devletin demokratik olup olmadığına dair adeta bir turnusol kağıdı işlevi görmektedir. ${ }^{1}$ Bu hakka işlerlik kazandırılması, demokratik sistemin etkili bir şekilde işleyebilmesi için merkezi bir önemdedir. ${ }^{2}$ Bu çalışmanın konusunu oluşturan dernekler ve vakıflar da özgürlükçü, çoğulcu ve demokratik toplumların yapı taşları arasında yer almaktadır. ${ }^{3}$ Kişilerin sahip oldukları farkı görüşlerin kristalize olması ve dile getirilebilmesi için toplumdaki farklı grupların bir araya gelmesi ve gruplar arasında karşıllklı etkileşim gereklidir. Örgütlenme özgürlüğ̈̈, özellikle bu tür bir işlev üstlenmektedir. ${ }^{4}$ Örgütlenme özgürlüğünün demokrasi ile yakından ilişkisi ve bu bağlamda taşıdığı önem Anayasa Mahkemesi (AYM) tarafindan da kabul edilmektedir. Mahkeme'ye göre, "Demokrasilerde vatandaşların bir araya gelerek ortak amaçları izleyebileceği örgütlerin varlığı sağlıklı bir toplumun önemli bir bileşenidir. Demokrasilerde böyle bir 'örgüt' devlet tarafından sayg1 gösterilmesi ve korunması gereken temel haklara sahiptir."

Örgütlenme özgürlüğ̈̈, İnsan Hakları Evrensel Beyannamesi'nin ${ }^{6} 20$. maddesinde, Türkiye'nin de tarafı olduğu Medeni ve Siyasal Haklar Uluslararası Sözleşmesi'nin 22. maddesinde ve Avrupa İnsan Hakları Sözleşmesi'nin (AİHS) ${ }^{8} 11$. maddesinde koruma altına alınmıştır. ${ }^{9}$ Anayasa'nın 90. maddesi doğrultusunda bu belgeler Türk hukukunun bir parçası haline gelmiştir ve belgelerde yer alan bazı normların uygun

\footnotetext{
Christian Tomuschat, "Freedom of Association", The European System for the Protection of Human Rights, R. St. J. Macdonald; F. Matscher; H. Petzold (eds), Martinus Nijhoff Publishers, the Netherlands, 1993, s. 498.

2 David Harris; Michael O'Boyle; Ed Bates; Carla Buckley, Harris, O'Boyle \& Warbrick, Law of the European Convention on Human Rights, Oxford University Press, Oxford, 2014, s. 710.

3 Rona Serozan, “Türkiye'de Dernek ve Vakıf Kurmanın ve Yürütmenin Zorlukları”, Bülent Tanör'e Armağan, Yayıma hazırlayan: Öget Öktem Tanör, Legal Yay., İstanbul, 2004, s. 550.

4 Tomuschat, s. 493.

5 AYM, Eğitim ve Bilim Emekçileri Sendikası ve Diğerleri Kararı, B. No: 2014/920, 25.05.2017, para 75.

6 BM Genel Kurulu tarafından 10.12.1948 tarihinde kabul edilmiştir. Bildiri’nin resmi Türkçe çevirisi için bkz, 27 Mayıs 1949 tarih ve 7217 sayılı Resmi Gazete.

7 Medeni ve Siyasi Haklara İlişkin Uluslararası Sözleşme 16.12.1966 tarihinde kabul edilmiş ve 23.03.1976 tarihinde yürürlüğe girmiştir. Sözleşme Türkiye tarafından 15.08.2000 tarihinde imzalanmış, 04.06.2003 tarihli ve 4868 sayılı Kanun ile onaylanmıştır. Sözleşme ile ilgili 2003/5851 sayılı Bakanlar Kurulu Kararı 25175 sayılı, 21.07 .2003 tarihli Resmi Gazete'de yayınlanmıştır. Sözleşme onay belgesinin 15.09.2003 tarihinde depo edilmesinin ardından 23.12.2003 tarihinde Türkiye bakımından hüküm doğurmuştur. Sözleşme'nin resmi Türkçe çevirisi için bkz, 25175 sayıll, 21.07 .2003 tarihli Resmi Gazete.

8 Insan Haklarını ve Temel Özgürlükleri Koruma Sözleşmesi 04.11.1950 tarihinde kabul edilmiş ve 03.09.1953 tarihinde yürürlüğe girmiştir. Türkiye Sözleşme'yi 04.11.1950 tarihinde imzalamış, 10.03.1954 tarihli ve 6366 sayılı Kanun ile onaylanmıştır. Sözleşme onay belgesinin 18.05.1954 tarihinde depo edilmesinin ardından aynı tarihte Türkiye bakımından hüküm doğurmuştur. Sözleşme'nin resmi Türkçe çevirisi için bkz, 19.03.1954 tarihli ve 8662 sayılı Resmi Gazete. Sözleșme'nin adı ile ilgili yaygın kullanım "Avrupa İnsan Hakları Sözleșmesi” șeklinde olduğu için çalıșmada bu isimle belirtilecektir.

9 Konuya ilişkin uluslararası sözleşme hükümleri için bkz, Nihal Jayawickrama, The Judicial Application of Human Rights Law: National, Regional and International Jurisprudence, Cambridge University Press, Cambridge, 2002, s. 735-738.
} 
olduğu durumlarda doğrudan uygulanabilmesi mümkündür. ${ }^{10}$ Ayrıca bu normların Türk hukukunda yürürlükte olan bir normun bir ihlale yol açmayacak biçimde yorumlanmasında dikkate alınması da yine uluslararası hukuktan ve Anayasa'dan kaynaklanan bir yükümlülüktür.

Anayasa'nın 90. maddesine göre örgütlenme özgürlüğü ile ilgili uluslararası sözleşmeler ile kanunlar arasında doğacak bir çatışmada öncelikle dikkate alınması gereken standartlar bu uluslararası sözleşmelerde yer alan veya özellikle Avrupa İnsan Hakları Mahkemesi (AİHM) ya da Birleşmiş Milletler İnsan Hakları Komitesi gibi denetim organları tarafından ortaya konulan standartlardır. ${ }^{11}$ Çalışmanın konusunu oluşturan kamu görevlilerinin örgütlenme hakkının kapsamının belirlenmesinde bu alanda ortaya çıkan uluslararası standartların göz ardı edilmesi mümkün değildir. AYM'ye göre de, 90. madde uyarınca,
“[...]temel hak ve özgürlüklere ilişkin uluslararası bir andlaşma ile bir kanun hükmünün çatışması halinde, uluslararası andlaşma hükmünün öncelikle uygulanması gerekir. Bu durumda başta yargı mercileri olmak üzere, birbiriyle çatışan temel hak ve özgürlüklere ilişkin bir uluslararası andlaşma hükmü ile bir kanun hükmünü önlerindeki olaya uygulamak durumunda olan uygulayıcıların, kanunu göz ardı ederek uluslararası andlaşmayı uygulama yükümlülükleri vardır." ${ }^{12}$

Örgütlenme özgürlüğü hakkının kapsamının belirlenebilmesi için öncelikle "örgüt” kavramının tanımlanması gerekmektedir. "Örgüt” kelimesi Türkçe' de “ortak bir amacı veya işi gerçekleştirmek için bir araya gelmiş kurumların veya kişilerin oluşturduğu birlik, teşekkül, teşkilat" olarak tanımlanmaktadır. ${ }^{13}$ AİHM, "örgüt” ifadesini AİHS'de yer alan diğer kavramlar gibi özerk bir biçimde yorumlamaktadır. ${ }^{14}$ Buna göre, bir "örgütün” ulusal hukukta "örgüt” olarak tanınmamış olması söz konusu oluşumun örgütlenme özgürlüğünden yararlanamayacağ1 anlamına gelmemektedir. ${ }^{15} \mathrm{Bu}$ nedenle örgütlenme özgürlüğünden yararlanma bakımından örgüt tarafından seçilen örgütlenme biçimi ve ulusal hukukun buna bağladığı hukuki sonuç belirleyici değildir. 16 "Örgüt”

\footnotetext{
10 Uluslararası andlaşmalar Anayasa'nın 90. maddesine göre kanun hükmünde olsa da bu durum andlaşmaların bir bütün olarak iç hukukta doğrudan uygulanabileceği anlamına gelmemektedir. Sözleşmelerin doğrudan uygulanabilir olması için "uygulama anında hiçbir tartışmaya firsat vermeyecek derecede, açık, ayrıntılı ve belirli olması gerektiği” öne sürülmektedir. Ancak bu çalışmanın sınırları dikkate alınarak örgütlenme özgürlüğüne ilișkin uluslararası hukukta ortaya çıkmış ve Türk hukukunun bir parçası haline gelmiş hükümlerin doğrudan uygulanabilir nitelikte olup olmadığı konusu üzerinde durulmamıştır.

11 Ancak AİHM gibi uluslararası mekanizmalar önüne örgütlenme özgürlüğü ile ilgili gelen şikayetler özellikle ya siyasi amaçlı kurulan örgütler veya örgütlerin siyasi faaliyetleri ya da sendikal özgürlüklerle ilgilidir. Konunun medeni yönüne ilişkin verilmiş karar sayısının oldukça az olduğunu belirtmek gerekir.

12 AYM, Sevim Akat Eşki Kararı, B. No: 2013/2187, 19.12.2013, para. 41; Adalet Mehtap Buluryer Kararı, B. No. 2013/5447, 16.10.2014, para. 46 .

13 Türk Dil Kurumu, Büyük Türkçe Sözlük, http://www.tdk.gov.tr/index.php?option=com_bts\&view=bts (erişim:01.05.2018)

14 Tomuschat, s. 494; P. Van Dijk; G.J.H. Van Hoof; Arjen Van Rijn; Leo Zwaak, Theory and Practice of the European Convention on Human Rights, Intersentia, Antwerpen, Oxford, 2006, s. 824. AİHM, Chassagnou and Others v. France, Appl. Nos: 25088/94 28331/95 28443/95, 29.04.1999, para 100.

15 Harris; O’Boyle; Bates; Buckley, s. 724.

16 Van Dijk; Van Hoof; Van Rijn; Zwaak, s. 824. Bu yaklaşım özelikle aşağıda üzerinden durulacak olan ve Türk hukuku tarafından kamu tüzel kişisi olarak kabul edilen kamu kurumu niteliğindeki meslek kuruluşlarının örgütlenme özgürlüğünün öznesi sayılıp sayılamayacağı sorunsalı bakımından büyük önem taşımaktadır.
} 
kavramı AYM tarafından AİHM kararlarına yapılan atıfla "kişilerin serbest iradeleriyle kurulan, ortak bir amaç için bir araya gelen kişiler topluluğu" olarak tanımlanmaktadır. ${ }^{17}$ Öğretiye bakıldığında ise "örgüt" kavramı iki veya daha fazla kişinin belirli bir ortak amacı gerçekleştirmek için süreklilik içinde ve asgari düzeyde de olsa bir teşekkül oluşturarak birlikte hareket etmesi olarak ${ }^{18}$, örgütlenme özgürlüğü ise bireylerin kendi menfaatlerini korumak için kendilerini temsil eden bir toplu teşekkül oluşturarak bir araya gelmeleri özgürlüğü olarak tanımlanmıştır. ${ }^{19}$

\section{B. Örgütlenme Özgürlüğünün Diğer Haklarla İlişkisi}

Örgütlenme özgürlüğü başka haklarla zaman zaman iç içe geçen bir haktır. Öncelikle bu hakka yer veren AİHS'nin 11. maddesi, hem toplanma özgürlüğünü, hem de örgütlenme özgürlüğünü güvence altına almıştır. Dolayısıyla bu iki kavramın birbirinden ayrıştırılması gerekmektedir. Örgüt tanımında yer alan süreklilik unsuru örgütlenme özgürlügünü toplanma özgürlüğünden ayıran temel unsurlardan birisidir. Toplanma özgürlüğünde ortak bir amaç için kısa süreli olarak bir araya gelinirken, örgütlenme özgürlüğünde bir örgüt çatısı altında bir amaç için sürekli olarak bir araya gelinmektedir. ${ }^{20}$

Örgütlenme ve toplanma özgürlükleri aynı zamanda ifade özgürlüğü ile de yakından ilişkilidir ve ifade özgürlüğü genel hüküm, örgütlenme ve toplanma özgürlüklerinin özel hüküm niteliğindedir. İfade özgürlüğü, diğer insan haklarından eksiksiz bir şekilde yararlanılmasının zeminini oluşturmaktadır ve toplanma ve örgütlenme özgürlüklerinin de ayrılmaz bir parçasıdır. ${ }^{21}$ AİHM de, bir örgütlenmenin amaçlarını ve görüşlerini özgürce dile getirememesi durumunda çoğulculuk ilkesinin yaşama geçirilmesinin mümkün olmadığını göz önünde tutarak, AİHS'nin 10. maddesi anlamında görüşlerin ve ifade özgürlüğünün korunmasının örgütlenme özgürlüğünün temel amaçlarından birisi olduğunu kabul etmektedir. ${ }^{22}$ Sayılan özgürlükler arasındaki bu yakın bağlantılı örgütlenme özgürlüğüne dair bir çalışmanın ister istemez diğer özgürlükleri de içermesi sonucunu doğurmaktadır. $\mathrm{Bu}$ nedenle çalışmada zaman zaman ifade özgürlüğü bağlamında gündeme gelen içtihatlara da gönderme yapılmıştır.

Örgütlenme özgürlüğ̈̈ ile birlikte zaman zaman gündeme gelen bir diğer özgürlük ise AİHS'nin 9. maddesinde, Anayasa'nın ise 24. maddesinde düzenlenen din veya inanç

17 AYM, Hüseyin Demirdizen Kararl, B. No: 2014/11286, 21.09.2016, para 35.

18 Tomuschat, s. 493; M. Kemal Oğuzman; Özer Seliçi; Saibe Oktay Özdemir, Kişiler Hukuku (Gerçek ve Tüzel Kişiler), Filiz Kitabevi, İstanbul, 2013, s. 240-241; Mustafa Dural; Tufan Öğ̈̈z, Türk Özel Hukuku, Cilt II, Kişiler Hukuku, Filiz Kitabevi, İstanbul, 2013, s. 209-211.

19 Harris; O’Boyle; Bates; Buckley, s. 724. Bu çalışmada "örgüt" kavramı bu tanımlardan hareketle zaman zaman yalnızca Türk hukukundaki verili örgütlenme biçimleri ile sınırlı olarak kullanılmayacaktır. Bu nedenle çalışmada "örgüt” kavramına özellikle dernek ve vakıfları aşan daha geniş bir anlam taşıdığı durumlarda başvurulmuş, diğer durumlarda ise dernek ve vakıf gibi somut bir örgüt biçimine gönderme yapılmıştır.

20 İlhan Akın, "Dernek Kurma Özgürlüğ̈̈”, İstanbul Üniversitesi Hukuk Fakültesi Mecmuası, Cilt 32, Sayı 2-4, İstanbul, 1966, s. 475.

21 Human Rights Committee, General Comment No. 34, Article 19: Freedoms of Opinion and Expression, para 4.

22 AïHM, Gorzelik v. Poland, Appl. No. 44158/98, 17.02.2004, para 91. 
özgürlüğüdür. Bu hak özellikle dini örgütlenmeler bakımından gündeme gelmektedir. Dini örgütlenmeler söz konusu olduğunda, din veya inanç özgürlüğü ile örgütlenme özgürlüğünün hangisi kapsamında bir değerlendirme yapılacağı sorusunun yanıtlanması gerekmektedir. Dini örgütlenmeler hem örgütlenme özgürlüğü hem de din veya inanç özgürlügü kapsamında gündeme gelen bir konudur. AIHHM'ye göre, “[i]]nananların, bir kişinin dinini diğerleri ile birlikte toplu halde açığa vurma hakkını da içeren din özgürlüğü hakk1, inananların devletin müdahalesi olmaksızın özgürce bir araya gelebilmeleri beklentisini de kapsamaktadır."23 $\mathrm{Bu}$ durumda AİHS'nin 11. maddesi AİHS'nin 9. maddesi ile birlikte değerlendirilmektedir. ${ }^{24}$ Çalışma kamu görevlilerinin dernek ve vakıflarda örgütlenmelerini ve örgütlenme özgürlüğünün medeni yönünü merkezine aldığı için dini örgütlenmeler bilinçli olarak kapsam dışında tutulmuştur.

\section{Hakkın Kullanılış Biçimleri}

\section{Genel Olarak}

Örgütlenme özgürlüğünün temelinde yatan "örgüt" kavramının geniş yorumlanmasının mümkün olduğu yukarıda ifade edilmişti. Bu hakkın hangi biçimlerde kullanılmasının mümkün olduğu sorusuna açık uçlu bir yanıt verilmesi mümkündür. Günümüzde bu hak siyasi parti, sendika, dernek ve vakıf gibi birçok örgütlenme biçimine koruma sağlamaktadır. Belirtilen biçimlerden hareketle hakkın hem medeni, hem siyasi, hem de ekonomik yönünün bulunduğunu söylemek mümkündür. Hakkın medeni yönü başka kişilerle bir araya gelmek isteyen kişilerin devlet tarafindan hukuka aykırı olarak müdahaleye maruz kalmamasına karşı koruma sağlarken, ekonomik yönü özellikle sendikalar yoluyla iş piyasasında bireylerin ekonomik menfaatlerinin geliştirmesini hedeflemektedir. Hakkın siyasi yönü ise bireylerin devlete veya diğer birey gruplarına karşı menfaatlerinin bir araya gelerek savunulmasına yardımcı olmaktadır. ${ }^{25}$ Ancak bu çalışmada hakkın yalnızca medeni yönü üzerinde, örgütlenme özgürlüğünün Türk hukukunda ortaya çıkmış başlıca biçimleri olan dernekler ve vakıflar üzerinde durulacaktır. ${ }^{26}$

\footnotetext{
AİHM, The Moscow Branch of the Salvation Army v. Russia, Appl. No. 72881/01, 05.10.2006, para 58.

24 Bununla birlikte çalıșma kapsamında dini örgütlenmeler konusuna değinilmemiștir. Türkiye bağlamında gündeme gelen ve "azınlık vakıfları" olarak adlandırılan Türkiye Cumhuriyeti vatandaşı olan gayrimüslim cemaatlere ait vakıflar azınlık vakıfları oldukça eski tarihlerde kurulmuştur ve diğer vakıflardan farklı statüye tabidir. Türkiye'de söz konusu cemaatlerin tüzel kişiliği bulunmamaktadır ve geçmişte kurulmuş olan vakıflar dışında cemaatlerce yeni vakıflar kurulamamaktadır. Bu nedenlerle çalışma kapsamında azınlık vakıflarına yer verilmemiştir. Elbette bu durum söz konusu vakıflar bakımından örgütlenme özgürlüğüne yönelik sınırlamaların veya sorunların mevcut olmadığı anlamına gelmemektedir.

25 Venice Commission, Opinion on the compatibility with human rights standards of the legislation on non-governmental organisations of the Republic of Azerbaijan, CDL-AD(2011)035, para. 40.

26 Çalıșmada "vakıf” kavramı yalnızca 743 sayılı Türk Kanunu Medenisi, 4721 sayılı Türk Medeni Kanunu ve 5737 sayılı Vakıflar Kanunu hükümlerine göre kurulan vakıflar için kullanılmaktadır. Türk Medeni Kanunu'na göre vakıflar, olağan vakıflar, istihdam edilenlere ve işçilere yardım vakıfları ve aile vakıflarından oluşmaktadır. Vakıflar Kanunu ise yeni, mazbut, mülhak, esnaf ve cemaat vakıfları biçiminde bir ayrıma gitmiştir. Çalışmada yalnızca Türk Medeni Kanunu'nda olağan vakıf olarak görülen ve herhangi bir özellik taşımayan vakıflar üzerinde durulmuş ve diğer vakıf türleri çalıșmanın kapsamı dışında tutulmuştur. Dernekler açısından mevzuatta bu şekilde bir ayrıma gidilmemiştir. Bu sebeple çalıșmada "dernek" kavramı "vakıf” kavramının aksine tüm dernekleri içerecek biçimde kullanılmıştır.
} 
Yukarıda da ifade edildiği gibi örgütlenme özgürlüğü ile ilgili uluslararası hukukta çok sayıda norm söz konusudur. Bu çalışmanın sınırları çerçevesinde büyük oranda AİHS kapsamında ortaya çıkan standartlara gönderme yapılacaktır. Bu alanda önde gelen temel düzenleme AİHS'nin 11. maddesidir. Maddeye göre “Herkes, barışç1l olarak toplanma özgürlüğü ve menfaatlerinin korumak için sendikalar kurmak ve sendikalara üye olmak da dahil, başkalarıyla birlikte örgütlenme özgürlüğü hakkına sahiptir." Belirtmek gerekir ki, AİHS'nin 11. maddesinde uygulamada ortaya çıkan örgütlerden yalnızca sendikalara doğrudan açık bir gönderme yapılmıştır. Bu durum AİHS'de sendikal özgürlüklere daha fazla hukuki değer atfedildiği anlamına gelmemektedir. AİHS'nin ortaya çıkış sürecinde sendikal özgürlüklerin birçok ülkede tehdit altında olmasından dolayı sendikalara madde metninde özellikle yer verilmiştir. ${ }^{27}$ Bunun yanında madde metninde yer alan “...da dahil” ifadesi 11. maddenin örgütlenmenin farklı biçimleri açısından açık uçlu olduğuna işaret etmektedir.

\section{Türkiye'de Mevcut Örgütlenme Biçimleri}

$\mathrm{Bu}$ hakkın kullanımı noktasında özel bir biçim belirlenmemekle birlikte, ${ }^{28}$ uygulamada belli örgütlenme biçimleri özellikle öne çıkmaktadır. Yaygın örgütlenme biçimleri olan dernek, vakıf, sendika ve siyasi parti Türkiye'de öne çıkan örgütlenme biçimleri olmuştur. Bununla birlikte sayılan örgütler gibi tüzel kişiliğe sahip olmamakla birlikte birden fazla kişinin belirli bir amacı gerçekleştirmek amacıyla gönüllü olarak bir araya geldiği her türlü oluşum örgütlenme özgürlüğünün kural olarak öznesidir. Yukarıda da belirtildiği üzere "örgüt” kavramı uluslararası hukukta özerk bir anlam taşımaktadır. AİHM'ye göre iç hukuktaki sınıflandırma ancak göreceli bir değer taşır ve başlangıç noktasından öte bir anlam taşımamaktadır. ${ }^{29}$ AİHM "örgüt” kavramına ilişkin bir tanımlama yapmamaktadır ve örgütlenme özgürlüğünün kapsamına girecek örgütleri içtihatlarla belirlemektedir. ${ }^{30} \mathrm{Bu}$ anlamda biçime dair tüketici bir liste sunmak mümkün gözükmemektedir. AYM'ye göre de “örgüt” kavramının Anayasa çerçevesinde özerk bir anlamı vardır ve bireylerin devamlı olarak ve eşgüdüm içerisinde yürüttükleri faaliyetlerin hukukumuzda örgütlenme olarak tanınmaması Anayasa hükümleri kapsamında örgütlenme özgürlüğünün zorunlu olarak gündeme gelmeyeceği anlamına gelmemektedir. ${ }^{31}$ Ortaya çıkan tanımlar ve her iki yargı organının içtihatları incelendiğinde çalışmanın konusunu oluşturan dernek ve vakıf gibi özel hukuka göre kurulan örgütlerin örgütlenme özgürlüğünün tartışmasız öznesi olduğu açıktır.

\footnotetext{
Tomuschat, s. 494.

28 Juan Maria Bilbao Ubillos, "Freedom of Assembly and Association (Art. 11 ECHR): Some Hesitations on a Path of Firm Protection", Europe of Rights: A Compendium of the European Convention of Human Rights, Pablo Santolaya Machetti; Javier Garcia Roca (Eds), Martinus Nijhoff, 2012, s. 411.

29 AilHM, Chassagnou and Others v. France, Appl. Nos: 25088/94 28331/95 28443/95, 29.04.1999, para 100.

30 Ersel Aldabak, “Avrupa İnsan Hakları Mahkemesi Kararlarında Örgütlenme Özgürlüğü”, Bülent Tanör 'e Armağan, Yayıma Hazırlayan: Öget Öktem Tanör, Legal Yay., İstanbul, 2004, s. 71.

31 AYM, Tayfun Cengiz Kararl, B. No: 2013/8463, 18.09.2014, para 30; Abidin Aydın Tüfekçi Kararı, B. No: 2013/1315, 15.04.2015, para 29.
} 
Örgütlenme özgürlügüne dair Türk hukukundaki temel düzenlemeler öncelikle Anayasa'da yer almaktadır. AİHS'nin 11. maddesi örgütlenme özgürlügünün tüm bu yönlerini zımni veya açık olarak birlikte düzenlerken, Anayasa konuyu 33, 51, 53, 54 ve 68. maddelerinde "Dernek Kurma Hürriyeti", "Sendika Kurma Hakkı" ve "Siyasi Parti Kurma Hakkı" başlıkları altında, dernekler ve vakıflar, sendikalar ve siyasi partiler açısından ayrı ayrı ve açıkça düzenlemiş̧ir. ${ }^{32}$ Çalışmanın kapsamı dikkate alınarak bu maddelerden yalnızca 33. madde üzerinde durulmuştur. Maddeye göre herkes önceden izin almaksızın dernek kurma, kurulmuş olan bir derneğe üye olma, bir derneğin üyeliğinden ayrılma özgürlüğüne sahiptir, hiç kimse bir derneğe üye olmaya veya bir dernekte üye kalmaya zorlanamayacaktır. Madde içeriği AİHS'nin 11. maddesinin sağladığı koruma ile paralel gözükmektedir. ${ }^{33}$ Sayılan tüzel kişiler harici, örneğin inisiyatif, girişim, öğrenci kulübü gibi örgütler kanunlar düzeyinde tanınmamaktadır ve tüzel kişiliğe sahip değildir. Bununla birlikte bu tür örgütler de örgütlenme özgürlüğünün birer öznesidir ve AİHS'nin 11. ve Anayasa'nın 33. maddelerinin koruması altındadır. Nitekim Anayasa'nın 33. maddesine ilişkin Danışma Meclisinde yapılan müzakerelerde madde metninde yer alan dernek ifadesinin geniş bir tabir olarak kullanıldığ 1 ve bir insan topluluğunun ifade edilmek istendiği özellikle vurgulanmıştı. ${ }^{34}$

Türk hukukunda örgütlenmeözgürlüğüne dairhukukiçerçeve örgütlenmenin biçimine göre farklılaşabilmektedir. Dernekler ve vakıflar Türkiye'de örgütlenme özgürlüğünün temel kullanım biçimleri olarak göze çarpmaktadır ve bu kurumlar bireylerin kendi kişisel olanakları ile tek başlarına gerçekleştiremeyecekleri amaçları, kendi varlıklarını aşan bir örgüt aracıllğılyla gerçekleştirmelerini sağlamaktadır. ${ }^{35}$ Dernekler ve vakıflar bakımından temel düzenlemeler Anayasa'nın 33. maddesi, 4721 Sayılı Türk Medeni Kanunu'nun (TMK) derneklere ve vakıflara ilişkin hükümleri ile 5253 Sayılı Dernekler Kanunu $^{36}$ ile 5737 Sayılı Vakıflar Kanunu'dur. ${ }^{37}$ Vakıflar Kanunu'nun 5. maddesinde yer alan "Yeni vakıflar; Türk Medeni Kanunu hükümlerine göre kurulur ve faaliyet gösterirler." ifadesi ve Dernekler Kanunu'nun 36. maddesinde yer alan "Bu Kanunda hüküm bulunmayan hallerde 4721 sayılı Türk Medeni Kanununun hükümleri uygulanır." ifadesi konu ile ilgili olarak TMK'yı da temel kanuni düzenlemelerden birisi haline

32 Anayasanın örgütlenme özgürlüğünün üç farklı biçimine ilişkin ayrıntılı bir çalışma için bkz, Selin Esen, "Role of the European Court of Human Rights in the Turkish Constitutional Court's Rulings Regarding the Freedom of Association", Rule of Law, Human Rights and Judicial Control of Power, Ius Gentium: Comparative Perspectives on Law and Justice, R. Arnold and J.I. Martínez-Estay (eds.), Springer, 2017.

33 Bu konuda bir inceleme için bkz, Olgun Akbulut, “Toplantı ve Örgütlenme Özgürlükleri”, İnsan Haklarl Avrupa Sözleşmesi ve Anayasa: Anayasa Mahkemesine Bireysel Başvuru Kapsamında Bir İnceleme, Sibel İnceoğlu (ed.), Beta Yay., İstanbul, 2013.

34 Danışma Meclisi Tutanak Dergisi, 8. Cilt, Birleşim 132, 21.08.1982, s. 322.

35 Serozan, “Türkiye’de Dernek ve Vakıf Kurmanın ve Yürütmenin Zorlukları”, s. 551.

36 Bu kanun ile derneklere ilişkin eski Dernekler Kanunu'na ilişkin bir karşıllaştırma için bkz, Sevtap Yokuş, "Dernek Özgürlüğü Çerçevesinde Türkiye'de Değişen Hukuksal Düzenlemeler”, Erdoğan Teziç'e Armağan, Galatasaray Üniversitesi Yayını, İstanbul, 2006, s. 259-267.

37 Çalışmanın doğrudan konusunu oluşturmayan sendikalar bakımından temel düzenlemeler ise Anayasa'nın 51., 53. ve 54 maddeleri ile 6356 Sayılı Sendikalar ve Toplu İş Sözleşmesi Kanunu ve 4688 Sayılı Kamu Görevlileri Sendikaları ve Toplu Sözleşme Kanunu'dur. Siyasi partiler bakımından ise temel düzenlemeler Anayasa'nın 68. ve 69. maddeleri ile 2820 Sayılı Siyasi Partiler Kanunu'ndan oluşmaktadır. 
getirmektedir. Dernekler Kanunu ve Vakıflar Kanunu özel ve sonraki kanun niteliğinde olduğu için TMK'ya göre öncelikle uygulanacaktır. TMK hükümleri ancak belirtilen iki kanunda hüküm bulunmadığı durumlarda uygulama alanı bulacaktır. Ancak TMK'da yer alan bir düzenleme özel hüküm niteliğinde ise diğer iki kanundan önce uygulama alanı bulabilmesi de mümkündür. ${ }^{38}$

Dernek, Dernekler Kanunu'nun 2. maddesinin a fikrasına göre "kazanç paylaşma dışında, kanunlarla yasaklanmamış belirli ve ortak bir amacı gerçekleştirmek üzere, en az yedi gerçek veya tüzel kişinin, bilgi ve çalışmalarını sürekli olarak birleştirmek suretiyle oluşturdukları tüzel kişiliğe sahip kişi topluluğu" olarak tanımlanmıştır. ${ }^{39}$ Dernekler, AYM'ye göre, “[...]bireylerin kendi menfaatlerini korumak ve savunmak, ideallerini ve ihtiyaçlarını gerçekleştirmek için kolektif oluşumlar meydana getirerek bir araya gelebilme özgürlüğü olan örgütlenme özgürlüğünün önemli bir parçasıdır." ${ }^{’ 0}$ Dernek kurma hakkı Anayasa'nın 33. maddesinde sayılanlar dışında bir derneğin etkinliklerine katılma ve dernek üyelerinin menfaatlerini korumak üzere faaliyette bulunma haklarını da içermektedir. ${ }^{41}$ Türkiye'de dernekler başlığı altında farklı kanunlarda düzenlenmiş, çocuk dernekleri, ${ }^{42}$ gençlik ve spor kulüpleri, ${ }^{43}$ spor kulüpleri, ${ }^{44}$ taraftar dernekleri, ${ }^{45}$ tüketici dernekleri ${ }^{46}$ ve emekli subay, emekli astsubay, harp malulü gaziler, şehit dul ve yetimleri ile muharip gazi dernekleri ${ }^{47}$ gibi alt kategoriler söz konusudur. ${ }^{48}$

Tüzel kişiliği olmamakla birlikte kurulabilecek bir diğer yapı ise platformlardır. Dernekler Kanunu'nun 2. maddesinde derneklerin kendi aralarında veya vakıf, sendika ve benzeri sivil toplum kuruluşlarıyla ortak bir amacı gerçekleştirmek üzere girişim, hareket ve benzeri adlarla geçici birliktelik oluşturabilecekleri ancak bu birlikteliklerin tüzel kişiliğinin bulunmayacağı düzenlenmiştir. Kanun'un 25. maddesine göre platform kurma hakkı derneklerin amaçları ile ilgisi bulunan ve kanunlarla yasaklanmayan alanlarda, kendi aralarında veya vakıf, sendika ve benzeri sivil toplum kuruluşlarıyla ortak bir amacı gerçekleştirmek üzere ve yetkili organlarının kararı ile kullanılabilecektir. ${ }^{49}$

\footnotetext{
Jale G. Akipek; Turgut Akıntürk; Derya Ateş, Türk Medeni Hukuku, Birinci Cilt, Başlangıç Hükümleri, Kişiler Hukuku, Beta, İstanbul, 2015, s. 102.

39 Çalışmada da bu tanım üzerinden hareket edilmektedir.

40 AYM, Hint Aseel Hayvanları Koruma ve Geliştirme Derneği ve Hikmet Neğuç Kararı, B. No: 2014/4711, 22.02.2017, para 41.

41 agk, para 43.

425253 say1l Dernekler Kanunu, madde 3.

435253 sayılı Dernekler Kanunu, madde 14.

446222 sayı1ı Spor Genel Müdürlüğü’nün Teşkilat ve Görevleri Hakkında Kanun, madde 20.

456222 sayılı Spor Genel Müdürlüğü’nün Teşkilat ve Görevleri Hakkında Kanun, madde 8.

466502 sayılı Tüketicinin Korunması Hakkında Kanun, madde 3.

472847 sayılı Türkiye Emekli Subaylar, Emekli Astsubaylar, Harp Malulü Gaziler, Şehit Dul ve Yetimleri ile Türkiye Muharip Gaziler Dernekleri Hakkında Kanun.

48 Türkiye'de dernek kurma hakkının tarihsel gelişimi için bkz, Metin Aslan, "Dernek Kurma Hürriyeti”, Galatasaray Üniversitesi Hukuk Fakültesi Dergisi, say1 2010/1, İstanbul, 2011, s. 1274-1282.

49 Kanun'da dernekler için öngörülen yasaklar platformlar için de öngörülmüştür. Dernekler Kanunu'nun 25. maddesine göre "Platformlar, kanunların dernekler için yasakladığı amaç ve faaliyet konuları doğrultusunda kurulamazlar ve faaliyet gösteremezler.
} 
Türkiye'de en yaygın örgütlenme modeli olan dernekler örgütlenme özgürlüğünün öznesi olmakla birlikte tüm örgütlenme biçimlerinin aynı derecede koruma gördüğünü söylemek mümkün değildir. AYM’ye göre, “Örgütlenme özgürlüğü ve onun bir alt türü olan dernek hakkı Anayasa kapsamında demokratik yaşamın ayrılmaz bir parçası olarak görüldüğünden bu hakka getirilecek sınırlandırmaların demokratik toplumda gerekli olup olmadığ1 sık1 denetim altındadır." ${ }^{\text {50 }}$ Bununla birlikte ifade özgürlüğü açısından da geçerli olduğu gibi siyasi konularda faaliyet yürüten derneklerle diğer konularda faaliyet yürüten dernekler, siyasi konularda faaliyet yürütmeyen bir dernek ile bir siyasi parti eşit düzeyde koruma görmeyebilmektedir. Siyasi konularda faaliyet yürüten dernekler veya siyasi partilere daha geniş bir koruma sağlandığı söylenebilir. ${ }^{51}$

"Vakıf" kavramı ise TMK'nın 101/1 maddesinde "gerçek veya tüzel kişilerin yeterli mal ve hakları belirli ve sürekli bir amaca özgülemeleriyle oluşan tüzel kişiliğe sahip mal topluluğu" olarak tanımlanmıştır. 01.05.2018 tarihi itibariyle AYM tarafından örgütlenme özgürlüğü bağlamında vakıflara ilişkin verilmiş herhangi bir karar göze çarpmamaktadır. Ancak yukarıda değinilen dernekler ile ilgili içtihatların vakıflar bakımından da geçerli olduğu söylenebilir.

\section{Tüzel Kişilik Sorunu}

Örgütlenme özgürlüğünün kullanma biçimi ile bağlantılı önemli bir konu tüzel kişilik sorunudur. Örgütlerin tüzel kişiliği haiz olanlar veya olmayanlar diye ayrılması mümkündür ancak tüzel kişiliğin bir örgütün örgütlenme özgürlüğünden yararlanmasının koşulu olmadığını belirtmek gerekir. Tüzel kişiliğe sahip bir örgüt, kurucusu veya üyelerinden ayrı bir varlığa sahip olabilecektir. ${ }^{52}$ Türkiye'de hukuken ancak tüzel kişiliğe sahip örgütler kurulabilmektedir. Türkiye'de tüzel kişiler TMK'nın 47. maddesinde "başlı başına bir varlığı olmak üzere örgütlenmiş kişi toplulukları ve belli bir amaca özgülenmiş olan bağımsız mal toplulukları..." olarak tanımlanmıştır. Tüzel kişilik için "sınırlı sayı" (numerus clausus) ilkesi geçerlidir ve kanunda açıkça belirtilenler dışında tüzel kişilik kazanılması mümkün değildir. burada gündeme gelen ikinci bir ilke ise tipe bağlllık ilkesidir ve mevcut yasal kalıplara yasalar tarafından saptanmış içerikten değişik yeni bir içerik ve işlev kazandırılamayacağı anlamına gelir..$^{53}$

TMK'nın 47. maddesine göre hukuka veya ahlâka aykırı kişi ve mal topluluklarının tüzel kişilik kazanamayacağı de ifade edilmiştir. Dernekler ve vakıflar haricinde kâr

Bu yasağa aykırı hareket edenler hakkında, bu Kanun ve ilgili kanunların cezai hükümleri uygulanır.” Bu durum derneklerin kanunda yer alan yasakları aşmak için çeşitli platformlar adı altında faaliyet yürütmelerini olanaksız hale getirmektedir.

50 AYM, Hint Aseel Hayvanları Koruma ve Geliştirme Derneği ve Hikmet Neğuç Kararı, B. No: 2014/4711, 22.02.2017, para 44.

51 AïHM, Vona v. Hungary, Appl. No: 35943/10, 09.07.2013, para 58.

52 Akipek; Akıntürk; Ateş, s. 501; Oğuzman; Seliçi; Özdemir, s. 240.

53 Rona Serozan, Medeni Hukuk: Genel Bölüm, Kişiler Hukuku, Vedat Kitapçılık, İstanbul, 2013, s. 501; Dural; Öğüz, s. 222. 
amacı gütmeyen şirket veya başka bir biçim altında herhangi bir örgüt kurulabilmesi mümkün kılınmamıştır. Bu başlı başına bir eksikliktir ve örgütlenme özgürlüğü tüzel kişiliğe sahip olmayan örgütler bakımından da güvence altına alınmalıdır ve örgüt biçimleri dernek ve vakıflarla sınırlı görülmemelidir. Dernekler ve vakıflar haricinde kanunlarda tüzel kişiliğe sahip kabul edilen istisnai kuruluşlar federasyonlar ve konfederasyonlardir. ${ }^{54}$

Bir "örgütün” tüzel kişilik taşıyıp taşımaması hakkın korumasından ne derece yararlanabileceğinin tespitinde önem kazanabilmektedir. Tüzel kişiliğe sahip olmak örgütlenme özgürlüğünü kullanan kişilerin faaliyet alanının genişlemesine olanak tanımaktadır. Ancak tüzel kişiliğe sahip olan örgütlerin sahip oldukları bu avantaj devletlere tüm örgütlenme biçimlerine tüzel kişilik tanıma yükümlülüğü altında olduğu anlamına gelmemektedir. ${ }^{55}$ Bununla birlikte, tüzel kişiliğe sahip olacak örgüt türlerinin sayısının az olmaması gerekmektedir. Türkiye'de bu anlamda yalnızca iki tür örgüt, dernekler ve vakıflar tüzel kişiliğe sahiptir ve bu sayı oldukça düşüktür.

Bir "örgütün” tüzel kişiliğe sahip olmaması üyelerini veya kendisini tek başına örgütlenme özgürlüğünün koruma alanının dışına çıkarmamaktadır. ${ }^{56}$ Gayrı resmi olmakla birlikte sürekli ve belirli bir amaca yönelik kümelenmeler örgütlenme özgürlügüünün kapsamına girmektedir. ${ }^{57}$ Bir örgütün tüzel kişilik kazanmasına dair bir zorunluluk öngörülmesi örgütlenme hakkına yönelik ağır bir sınırlama kabul edilebilir. Bu durum özellikle tescil zorunluluğu ile birlikte kamu makamlarının keyfi biçimde tescil usulünü zorlaştırması, tescil talebinin reddedilmesi, tescil talebine geç cevap verilmesi ${ }^{58}$ veya hiç cevap verilmemesi gibi durumlarda örgütlenme özgürlüğünün ihlaline yol açabilecektir. Ayrıca bir örgüt devlet tarafindan, önüne üstesinden gelinmesi zor koşullar getirilerek ve böylece örgütlenme özgürlüğ̈̈nü etkili bir şekilde kullanması engellenerek, istemediği bir tüzel kişilik biçimi benimsemeye de zorlanmamalıdır. ${ }^{59}$

\section{D- Örgütlenmenin Amacı}

Örgütlenme özgürlügüne dair gündeme gelen diğer bir soru hangi amaçlarla “örgüt” kurulabileceği sorusudur. Kural olarak, örgütlenmenin amacı örgütlenme özgürlüğünden yararlanma açısından belirleyici değildir. Uluslararası hukukta ve Anayasa'da bir araya gelen kişilerin ortaklaştıkları amacın kapsamına ilişkin per se

\footnotetext{
4 Çalışmada bilinçli olarak bu iki örgüt biçimi üzerinde durulmamıştır.

Harris; O’Boyle; Bates; Buckley, s. 738.

56 Maina Kiai, Report of the Special Rapporteur on the rights to freedom of peaceful assembly and of association, A/ HRC/20/27, 21.05.2012, para 56.

57 Harris, O’Boyle, Bates, Buckley, s. 724.

58 Human Rights Committee, Kuwait, A/55/40 vol. I (2000) 65, para 489.

59 AİHM, Zhechev v. Bulgaria, Appl. No: 57045/00, 21.06.2007,para 56.
} 
bir sinırlama söz konusu değildir. ${ }^{60}$ AİHS'nin 11. maddesinde yer alan "menfaatlerini korumak için" ifadesi de amaç bakımından bir sınırlamanın mevcut olmadığına işaret etmektedir. Bugün için, herhangi bir grup veya kişi ya da herhangi bir tüzel kişinin ortak menfaatleri doğrultusunda toplu olarak hareket etmek, düşüncelerini açıklamak, bunları yaymak, gözetmek ya da savunmak için bir araya gelmesi "örgüt" olarak kabul edilmeleri bakımından yeterli kabul edilmektedir. ${ }^{61}$

Belirleyici olan söz konusu "örgütün" işleyişinin devletten bağımsız olmasıdır. ${ }^{2}$ Bir örgütün devletten bağımsız olduğu durumda etnik, dinsel, dilsel, kültürel, toplumsal, siyasal, mesleki, spora yönelik veya yardım amaçlı olarak kurulması mümkündür. ${ }^{63}$ AYM de örgütlenme özgürlüğünün kullanılma amacı noktasında bir sınırlamaya gitmemektedir. Mahkeme’ye göre “örgütlenme özgürlüğü, bireylere topluluk halinde siyasal, kültürel, sosyal ve ekonomik amaçlarını gerçekleştirme imkânı sağlar." ${ }^{\prime 4} H a k k ı n$ hangi amaçla kullanılabileceğine dönük herhangi bir sınırlamanın olmaması her türlü bir araya gelişin örgütlenme özgürlüğünden yararlanabileceği anlamına gelmemektedir. Örneğin geçmişte cezaevinde mahpusların "arkadaşlık" amacıyla bir araya gelerek oluşturdukları bir kişi grubu "örgüt" olarak görülmemiştir. ${ }^{65}$ Bir araya gelişin arızi nitelikte olması durumunda bir örgütten bahsetmek mümkün değildir. ${ }^{66}$

“Örgüt” kavramı Türkiye'de genellikle siyasi bağlamda kullanılan bir kavram olmakla birlikte kavram yalnızca siyasi amaçla kurulan oluşumları kapsamamaktadır. $\mathrm{Bu}$ yaklaşımın izini aşağıda kamu görevlilerinin derneklerde veya vakıflarda örgütlenmesine getirilmiş katı yasaklarda sürmek mümkündür. Ancak siyasi amaçlarla kurulan "örgütleri” diğer amaçlarla kurulan örgütlerle ayıran en önemli husus örgütlenme özgürlüğü kapsamında sağlanan korumanın dar veya geniş olmasıdır. Yukarıda da belirtildiği gibi örgütlenme özgürlüğünde siyasi amaçlı kurulan "örgütler" daha geniş bir korumadan yararlanabilmektedir. ${ }^{67}$ Ancak siyasi bir amacı bulunmayan "örgütler" de siyasi "örgütler" gibi aynı sınırlama rejimine tabidir. Hatta siyasi amaçlı olmayan, örneğin çevrenin korunmasını amaçlayan bir "örgüt" de AİHM ${ }^{68}$ ve Venedik Komisyonu ${ }^{69}$ tarafindan demokrasinin mevcudiyeti ve iyi bir şekilde işleyebilmesi bakımından önemli kabul edilebilmektedir.

\footnotetext{
60 AïHM, Sidiropoulos v. Greece, Appl. No: 26695/95, 10.07.1998, para 40.

${ }^{61}$ Kiai, para 51.

62 Akbulut, s. 397.

${ }^{63}$ Bernadete Rainey; Elizabeth Wicks; Clare Ovey, Jacobs, White, Ovey, The European Convention on Human Rights, Oxford University Press, Oxford, 2014, s. 481; Jayawickrama, s. 738.

${ }_{64}$ AYM, Tayfun Cengiz Kararl, B. No: 2013/8463, 18.09.2014, para 32; Abidin Aydın Tüfekçi Kararl, B. No: 2013/1315, 15.04.2015, para 31 .

65 AïHK, McFeeley v. the United Kingdom, Appl. No. 8317/78, 15.05.1980, para 114.

66 Tomuschat, s. 494.

${ }_{67}$ Harris; O’Boyle; Bates; Buckley, s. 731. Ayrıca bkz, AİHM, Les Authentiks and Supras Auteuil 91 v. France, Appl. No. 4696/11 and 4703/11, 27.10.2016, para 84.

68 AİHM, Tebieti Mühafize Cemiyyeti and Israfilov v. Azerbaycan, Appl. No. 37083/03, 08.10.2009, para. 53.

69 Venice Commission, Opinion on the compatibility with universal human rights standards on the article 193-1 of the criminal code on the rights of non-registred associations of the Republic of Belarus, CDL-AD(2011)036, para. 63.
} 


\section{E- Hakkın Öznesi}

\section{Genel Olarak}

AİHS'nin 11. maddesine ve Anayasa'nın 33. maddesine göre örgütlenme özgürlüğünün öznesi herkestir. Hakkı kullanmak isteyen kişinin Türkiye Cumhuriyeti vatandaşı olması veya olmaması ya da vatansı olması, gerçek kişi veya tüzel kişi olması hakkın öznesi olup olmama bakımından bir önem taşımamaktadır. Hem yabancılar, hem de tüzel kişiler bu hakkın yararlanıcılarıdır. ${ }^{70}$ Anayasa'nın 33. maddesinde 2001 yılında yapılan değişikliğin gerekçesine göre de "Maddede geçen 'herkes' kavramı her hukuki varlığı, tüzelkişileri de kapsar. Tüzelkişiler dernek kurabilir ya da derneğe üye olabilir."71

\section{Kamu Görevlileri}

Gerek uluslararası alanda gerekse Türkiye'de kamu görevlilerinin örgütlenme özgürlüğü konusu ağırlıklı olarak sendikal örgütlenme ile bağlantılı olarak tartışılmış, özgürlügüun medeni hukuk yönü çoğunlukla göz ardı edilmiştir. Öğretide bu konuya odaklanmış neredeyse hiç bir çalışma bulunmamaktadır. Bu çalışma bu alandaki bir eksikliği giderme çabası olarak okunmalıdır.

AİHS'nin 11. maddesinin son cümlesi, "Bu madde, bu hakların silahlı kuvvetler, emniyet veya devlet idaresi mensuplarınca kullanılmasına hukuka uygun olarak k1sitlama getirilmesini engellemeyecektir” şeklindedir. Görüldüğü üzere AİHS taraf devletlerin kamu görevlilerinin örgütlenme özgürlüğüne kısıtlama getirmelerine olanak tanımıştır. Elbette bu kısıtlamalar bu özgürlükler için 11. maddenin ikinci paragrafindan öngörülmüş olan sınırlama rejimine uygun olacaktır. Maddede kamu görevlilerine ilişkin cümlede yer alan "hukuka uygun" ifadesi, kamu görevlileri bakımından da genel sinırlama rejimine uygun bir değerlendirme yapılmasını gerektirdiği şeklinde yorumlanmıştır. ${ }^{72}$ Buna ek olarak söz konusu ifade kamu görevlilerinin örgütlenme özgürlüğüne Sözleşme anlamda bir sınır getirmemekte, yalnızca yasa koyucunun sınırlama rejimine uygun olmak kaydıyla kamu görevlilerinin örgütlenme özgürlüğünü sınırlanabileceği anlamına gelmektedir. Bu nedenle kamu görevlilerinin örgütlenme özgürlüğünün kapsamı Sözleşme ile daraltılmış değildir.

AİHS'nin 11. maddesindeki benzer bir ifadeye Anayasa'nın 33. maddesinin altıncı fikrasında da yer verilmiştir: "Birinci fikra hükmü, Silahlı Kuvvetler ve kolluk kuvvetleri mensuplarına ve görevlerinin gerektirdiği ölçüde Devlet memurlarına kanunla sınırlamalar getirilmesine engel değildir." Geçmişte söz konusu ifadenin

\footnotetext{
Tomuschat, s. 497-498.

Türkiye Cumhuriyeti Anayasası, Madde Gerekçeli, TBMM, Ankara, 2011, s. 62.

72 Van Dijk; Van Hoof; Van Rijn; Zwaak, s. 839.
} 
AİHS'nin 11. maddesinden alındığı belirtilmiştir. ${ }^{73}$ Anayasa'nın 33. maddesinin altıncı fikrası, maddenin ilk fikrasına gönderme yapmıştır ve kamu görevlilerinin önceden izin almaksızın dernek ve vakıf kurma ve bunlara üye olma ya da üyelikten çıkma özgürlüklerine kanunla sınırlama getirilmesine olanak tanımıştır. Düzenlemenin gerekçesinde şu ifadelere yer verilmiştir: "Dernek kurma özgürlüğü bazı meslek mensupları konusunda, bu kişilerin üstlendiği görevin niteliği nedeniyle başkaca sinırlamaya konu olabilecek yahut tamamen yasaklanabilecektir. Bunlar özel bir disipline gerek gösteren Silahlı Kuvvetler yahut kolluk kuvvetleri mensupları ile dernekleşme yüzünden görevin zarar görebileceği kamu görevlileridir. Bu husus, birinci fikra hükmünün bir istisnası olmak üzere maddenin altıncı fikrasında yer almaktadır."’74

Ancak belirtilen gerekçe, maddenin orijinal metnine ilişkin bir açıklama getirmektedir. Maddenin orijinal metninde ilgili fikra "Birinci fikra hükmü, Silahlı Kuvvetler ve kolluk kuvvetleri mensupları ile kamu hizmeti görevlilerinin dernek kurma haklarına başkaca sınırlamalar getirilmesine veya bu hürriyeti kullanmalarının yasaklanmasına engel değildir." şeklinde kaleme alınmıştı. 1995 yılında yapılan değişiklikle maddenin ilgili fikra metni bugünkü haline gelmiştir. ${ }^{75}$ Türk Silahlı Kuvvetleri (TSK) mensupları ve kolluk kuvvetleri mensupları açısından dernek ve vakıflarda örgütlenme özgürlüğünün yasaklanabileceği biçimindeki ifade ortadan kaldırılmıştır. Dolayısıyla çalışmanın konusunu oluşturan TSK ve genel kolluk mensupları ${ }^{76}$ açısından hakkın tamamen ortadan kaldırılması olanağı kalmamıştır. İkinci olarak ise belirtilenler haricindeki kamu görevlilerinin tamamına değil ancak "görevlerinin gerektirdiği ölçüde" sinırlama getirilebilecektir. Görüldüğü üzere, TSK ve genel kolluk mensupları gibi geri kalan kamu görevlilerinin de dernek ve vakıflarda örgütlenme özgürlüğünün yasaklanması artık mümkün değildir.

Anayasa'nın 33. maddesinin orijinal metninde yer alan "yasaklanabilir" ifadesi ile kamu görevlilerinin dernek ve vakıflarda örgütlenme özgürlügünün tamamen yasaklanabilmesi olanaklı kılınmak istenmiştir. Danışma Meclisi’nde yürütülen tartışmalarda da "silahlı kuvvet ve kolluk kuvvetlerinin dernek kurmalarını engellemekte insan haklarıyla bağdaşmayan bir yan" olmadığı vurgulanmıştır. ${ }^{77}$ Ancak, maddenin gerekçesinde dile getirilen amaç metnin bugünkü hali ile artık uyumlu değildir. Metin üzerinde durulan gerekçenin tam aksi bir yoruma izin

73 Danışma Meclisi Tutanak Dergisi, 8. Cilt, Birleşim 132, 21.08.1982, s. 322.

74 Türkiye Cumhuriyeti Anayasa Tasarısı ve Anayasa Komisyon Raporu, 1/463, S. Sayısı 166'ya 1inci Ek, s. 22, https://www. tbmm.gov.tr/tutanaklar/TUTANAK/DM__d02/c007/dm_02007120ss0166ek01.pdf (erişim:01.05.2018)

75 Bkz, 4721 sayılı 2709 sayılı Türkiye Cumhuriyeti Anayasasının Başlangıç Metni ve Bazı Maddelerinin Değiştirilmesine Dair Kanun, 26.07.1995 tarihli ve 22355 sayılı Resmi Gazete.

76 Kuruluş kanunlarına göre Emniyet Genel Müdürlüğü, Sahil Güvenlik Komutanlığı ve Jandarma Genel Komutanlığ mensupları genel kolluk kuvveti olarak adlandırılmıștır. Bkz, 2692 sayılı Sahil Güvenlik Komutanlığı Kanunu (09.07.1982 tarihli ve 17753 sayılı Resmi Gazete), 2. madde; 2803 sayılı Jandarma Teşkilat, Görev ve Yetkileri Kanunu (12.03.1983 tarihli ve 17985 sayılı Resmi Gazete), 3. madde; 3201 sayılı Emniyet Teşkilatı Kanunu (12.06.1937 tarihli ve 3629 sayılı Resmi Gazete). Çalışmada "genel kolluk" kavramı bu kurumlarda çalışan kamu görevlileri anlamında kullanılmıştır.

77 Danışma Meclisi Tutanak Dergisi, 8. Cilt, Birleşim 132, 21.08.1982, s. 322. 
verir niteliktedir. Ayrıca maddenin Danışma Meclisi'nde müzakeresi sırasında dile getirilen ifadenin AİHS'nin 11. maddesinden alındığına ilişkin beyan da bu düşünceyi desteklemektedir. ${ }^{78}$

Sonuç olarak, AİHS'nin 11. maddesinde olduğu gibi burada da bu tür sınırlamaların Anayasa'nın 13. maddesinde düzenlenmiş olan sınırlama rejimine uygun olması gerekmektedir. Dolayısıyla her ne kadar her iki maddede de kamu görevlileri için devlete bir takdir alanı bırakılmış olsa da, bu durum kamu görevlilerinin örgütlenme özgürlüğünün olmadığı anlamına gelmemektedir ve herhangi bir kısıtlama sınırlama rejimine uygun bir şekilde getirilmiş olmalıdır.

Kamu görevlilerinin örgütlenme özgürlüğünün öznesi olduğunun kabulünün ardından bu kişilerce bu özgürlüğün ne şekilde kullanabileceği sorusu yanıtlanmalıdır. $\mathrm{Bu}$ bakımdan öncelikle kamu görevlilerinin örgütlenme özgürlüğüne kısıtlama getirilmesini olanaklı kılan bu düzenlemelerin ne amaçla getirildiğine bakılmalıdır. AİHS’nin 11. maddesindeki kamu görevlilerine ilişkin ifadenin amac1, kamu görevlilerinin toplu eylemlerinin vatandaşların kamu hizmetlerinin bütünlüğü, nesnelliği ve tarafsızlığına duyduğu güveni, özellikle de çatışan toplumsal güçler arasından hakem rolü oynamak durumunda olduğu bir kriz durumunda tehlikeye atabilecek olması gösterilmiştir. ${ }^{79}$

AYM de doğrudan dernek ve vakıflarla ilgili olmasa da, sendikalara ilişkin bir kararında farklı bir gerekçe ile de olsa benzer bir tutum sergilemiştir. AYM, sendika kurma ve sendika üyesi olma hakkının kapsamı dışında tutulan kamu görevlileri ile ilgili kanun hükmüne ilişkin olarak, bu kişilerin sendikalaşmalarının kamu kurumlarının çalışma düzenini olumsuz etkileme potansiyeli olduğunu, ancak bu durumun işin doğasından kaynaklandığını ve bu gerekçeyle sendika kurma hakkının ortadan kaldırılmasının demokratik toplum gerekleriyle örtüşmeyeceği görüşündedir. Ancak Mahkeme’ye göre, “katı bir disiplin ve hiyerarşik düzen gerektiren kimi mesleklerde çalışma düzeninin bozulması, kamu düzeninin de telafisi mümkün olmayacak şekilde bozulmasına neden olabileceğinden bu gibi durumlarda, kamusal yarara üstünlük tanınarak ilgili mesleklerle sınırlı olarak sendikalaşmanın yasaklanması söz konusu olabilir." 80 Kamu görevlilerinin dernek ve vakıflarda örgütlenmesine dair konular AYM önüne geldiğinde Mahkeme tarafından benzer bir yaklaşım sergilenmesi olasıdır.

Belirtmek gerekir ki, yukarıda dile getirilen kaygıların günümüzde bazı kamu görevlilerinin kategorik olarak örgütlenme özgürlüğ̈ünden yoksun bırakılmasına gerekçe oluşturması mümkün gözükmemektedir. Anılan düzenlemeler sayılan kişilerin hakkın öznesi olmadığı anlamına gelmemekte, yalnızca devletlere bu konuda

\footnotetext{
age.

79 Tomuschat, s. 511.

${ }^{80}$ AYM, E. 2015/62, K. 2015/84, 30.09.2015, para. 16.
} 
daha geniş bir takdir alanı bırakıldığına işaret etmektedir. Söz konusu düzenlemeler, getirilecek bir sınırlama için devletlere verilmiş açık çek niteliğinde değildir. ${ }^{81}$ İlgili düzenlemelerin günümüz koşullarında yukarıda belirtildiği amaç doğrultusunda ve dar biçimde yorumlanması gerekmektedir. Bu tür bir yaklaşımla birlikte TSK ve genel kolluk mensuplarının kategorik olarak örgütlenme özgürlüğünden yoksun bırakılmaması, bu meslek içerisinde yer alan ve belirli görevleri yerine getiren kişiler bakımından örgütlenme özgürlüğünün yolunun açılması olanaklı hale gelebilecektir.

Bugün için AİHS ve Anayasa'da kamu görevlilerinin örgütlenme özgürlüğüne yönelik yer alan ifadelerin örgütün türüne ve amacına bakılmaksızın her türden örgüte üyeliğin yasaklanmasına dayanak oluşturması mümkün gözükmemektedir. ${ }^{82} \mathrm{Bu}$ durum aşağıda daha ayrıntılı görüleceği üzere TSK ve genel kolluk mensupları için dahi geçerlidir. ${ }^{83}$ Ayrıca AİHS'nin 11. maddesinde yer verilen "devlet idaresi mensupları" ifadesi AİHM tarafindan devlet memurlarının büyük çoğunluğunu içermeyecek biçimde ve dar yorumlanmaktadır. ${ }^{84}$ Örneğin belediye çalışanları bu kapsamda görülmemiştir. ${ }^{85}$ Mahkeme'ye göre "devlet idaresi" kavramı kamu görevlisinin yürüttügü faaliyet dikkate alınarak dar yorumlanmalıdır. ${ }^{86}$ Devletin kamu görevlilerinin örgütlenme özgürlüğüne yönelik getireceği mutlak bir yasak örgütlenme özgürlügüne doğrudan aykırılık oluşturacaktır. Bunun için devletin ikna edici ve inandırıcı gerekçelerin somut delillerle ortaya koyması gerekmektedir ve devlete bırakılan takdir alanının kapsamı oldukça dardır. ${ }^{87}$ Anayasa'nın 33. maddesinde yer verilen "görevlerinin gerektirdiği ölçüde" ifadesi ise AİHS'nin 11. maddesinin aksine "devlet memurlarının" tamamına ilişkin bir kısıtlamaya olanak tanımamaktadır.

Öte yandan bu şekilde bir yaklaşım kamu görevlilerinin örgütlenme özgürlüğünün sınırsız olduğu anlamına gelmemektedir ve bu kişilerin bulundukları konum ve görev yaptıkları alanlar, örgütlenme özgürlüğünden sınırlı bir şekilde yararlanmaları sonucunu doğurabilecektir. Örneğin polis memurlarının örgütlenme özgürlüğünü siyasi amaçlarla kullanması durumunda devlet tarafından yaptırım uygulanması, söz konusu yaptırımlar ölçülülük ilkesine uygun olduğu ${ }^{88}$ ve polis memurlarının siyasi görüşlerini dile getirme özgürlügüü bütünüyle ortadan kaldırılmadığg ${ }^{89}$ sürece örgütlenme özgürlüğünün ihlali olarak görülmeyebilmektedir. Kamu görevlilerinin örgütlenme özgürlüğünün kapsamının kamu görevlisi olmayan kişilere göre daha dar olması örgütlenme özgürlüğüne aykırılık oluşturmayabilecektir.

\footnotetext{
AïHM, Tüm Haber Sen and Çınar v. Turkey, Appl. No: 28602/95, 21.02.2006.

$\$ 2$ Akbulut, s. 382.

83 Harris; O’Boyle; Bates; Buckley, para. 750.

${ }^{84}$ AïHM, Vogt v. Germany, Appl. No: 17851/91, 26.09.1995, para. 67.

85 AïHM, Demir and Baykara v. Turkey, Appl. No. 34503/97, 12.11.2008, para. 107.

86 AİHM, Vogt v. Germany, Appl. No. 17851/91, 26.09.1995, para 67.

87 Harris; O’Boyle; Bates; Buckley, para. 751.

88 AİHM, Trade Union of the Police in the Slovak Republic and Others v. Slovakia, Appl. No. 11828/08, 25.09.2012.

89 AİHM, Rekvenyi v. Hungary, Appl. No. 25390/94, 20.05.1999, para. 47-49.
} 
$\mathrm{Bu}$ anlamda hakkın kapsamına ilişkin polis ve asker gibi kamu görevlileri ile diğer kamu görevlileri arasında ayrım yapılması mümkündür. ${ }^{90}$ İlk grupta yer alan kamu görevlilerinin özellikle siyasi amaçlı olarak örgütlenmelerinin yasaklanması örgütlenme özgürlüğüne aykırı bulunmayabilmektedir. ${ }^{91}$ Ancak yine de polis veya asker gibi kamu görevlilerinin örgütlenme özgürlüğünün tamamen yasaklanması örgütlenme özgürlüğünün ihlaline yol açabilecektir.92 ${ }^{92}$ Bununla birlikte siyasi faaliyetler, özellikle de siyasi parti üyeliği söz konusu olduğunda devletin takdir alanı genişleyebilmektedir. ${ }^{93}$ Siyasi amaçlı örgütlenmenin kısıtlanması askerlerin veya polis memurlarının örgütlenme özgürlüğü olmadığı anlamına gelmemektedir. $\mathrm{Bu}$ meslek gruplarında yer alan kamu görevlilerinin mesleki sorunları çerçevesinde sendika veya benzeri şekillerde bir araya gelmesinin yasaklanması örgütlenme özgürlüğünün ihlalidir. ${ }^{94}$ Nitekim Avrupa Konseyi Parlamenterler Meclisi de 2002 yılında "üniformalı vatandaş" olarak adlandırdığı askerlerin ordunun muharebe halinde olmadığ1 zamanlarda demokratik kurumlar çerçevesinde kendi mesleki menfaatlerini korumak amacıyla belirli örgütler kurma, bunlara katılma ve etkin bir şekilde bunlar içerisinde faaliyet yürütme haklarından yararlanması gerektiğini belirtmiştir. ${ }^{95}$ Kamu görevlilerine getirilen bir sınırlama meşru kabul edilse dahi yine de örgütlenme özgürlüğü bakımından uygulanagelen sınırlama rejimine tabidir ve bu noktada kamu görevlisinin yürüttüğü görev, yalnızca devletin takdir alanının daralmasına veya genişlemesine yol açmaktadır. ${ }^{96}$

AYM de, AİHM gibi TSK ve genel kolluk mensupları ile diğer kamu görevlileri arasında bir ayrıma gitmektedir. Mahkeme’ye göre kamu görevlilerine dönük kategorik bir yasak örgütlenme özgürlüğüne aykırı oluşturabilecektir. Örneğin AYM, 4688 sayılı Kamu Görevlileri Sendikaları ve Toplu Sözleşme Kanunu'nun 15. maddesinde yer alan TBMM Başkanlığı idari teşkilatında görev yapan personelin sendika hakkından yararlanamamasına dair düzenleme bakımından ikna edici ve zorlayıcı gerekçelerin bulunmadığını ve sendika hakkına yapılan müdahalenin demokratik toplum düzeni açısından gerekli bir müdahale niteliğini taşımadığını kabul etmiştir: ${ }^{97}$

"[Bu kişilerin] sendikalaşmasının, çalışma düzeni üzerinde yaratacağ etkinin, bunların sendika kurma hakkından yoksun bırakılmalarını zorunlu kıldiğı söylenemez. Zira bu kişilerin yürüttüğ̈̈ hizmetlerde meydana gelebilecek aksamalar, yasama organının çalı̧̧ma düzeni

\footnotetext{
Aldabak, s. 96.

AİHM, Rekvenyi v. Hungary, Appl. No. 25390/94, 20.05.1999, para. 60-61.

92 Kiai, para. 54

93 AïHM, Strzelecki v. Poland, Appl. No. 26648/03, 10.04.2012, para. 51-58.

94 AİH, Matelly v. France, Appl. No. 10609/10, 02.10.2014; ADEFDROMIL v. France, Appl. No. 32191/09, 02.10.2014.

95 Council of Europe Parliamentary Assembly, Recommendation 1572 (2002), Right to association for members of the professional staff of the armed forces, http:/www.assembly.coe.int/nw/xml/XRef/Xref-XML2HTML-EN. asp?fileid $=17031 \&$ lang $=$ en (erişim:01.05.2018)

96 Aldabak, s. 98.

97 AYM, E. 2015/62, K. 2015/84, 30.09.2015, para. 18-19
} 
yönünden telafisi güç ve imkânsız zararların oluşmasina yol açmamaktadır. Dolaylsıyla, TBMM Başkanliğl idari teşkilatında görev yapan personelin sendika kurma hakkından yoksun bırakılmasının, demokratik toplum düzeni bakımından zorunluluk taşıdığı söylenemez. "98

Yeri gelmişken AYM tarafindan kullanılan "telafisi güç veya imkansız zarar" ölçütünün örgütlenme özgürlüğünden yararlanacak kişilerin belirlenmesinde işlevli bir ölçüt olmadığını ifade etmek gerekir. Bu tür bir ölçütün kabulü mantıksal olarak kimi kamu hizmetlerinin yerine getirilmemesi durumunda "telafisi güç veya imkansız zarar" doğmayacağı biçiminde bir sonuca ulaştıracaktır. Hangi kamu hizmetlerinin bu kapsamda görülebileceği, hangilerinin görülmeyebileceğinin önceden belirlenmesi oldukça güçtür. Bunun yanında herhangi bir kamu hizmetini gören kişilerin ilgili kamu hizmetinin farklı boyutları bakımından görev üstlenmesi durumunda ilgili yasağın kapsamında bulunmasının bir anlamı olmayabilir. Örneğin AYM önüne gelen düzenleme TBMM Başkanlığı idari teşkilatında görev yapan kişilerle ilgilidir. TBMM'nin yasama yetkisinin kullanımında görev yapan veya idari nitelikteki işlerini yerine getiren görevliler bakımından aynı şekilde belirtilen ölçütün uygulanması ölçüsüz bir sınırlamaya yol açacaktır. Yasama yetkisinin kullanılamamasının bu tür bir etki doğurması mümkün olsa da diğer görevlilerin yerine getirdikleri görevler açısından bu tür bir etki doğması mümkün değildir. Kaldı ki sendikalaşmanın nasıl "telafisi güç veya imkansız zarar" doğurabileceği de belirsizdir. AYM'nin bu tutumu sendikalaşmanın örgütlenme özgürlüğünün Anayasal bir biçimi olmak yerine 1982 Anayasasının orijinal metninde olduğu gibi hala bir "tehdit" olarak algılandığına işaret etmektedir.

AYM'nin yukarıda değinilen kararı asker veya polis dışında kalan kamu görevlilerine ilişkindir. Asker ve polis gibi kamu görevlileri ile ilgili olarak verdiği başka bir kararda ise emniyet hizmetleri sınıfına mensup kamu görevlilerine yönelik sendika yasağı değerlendirilmiş̧ir. AYM bu kez bu kişilere yönelik sendika kurma ve sendikalara üye olma yasağını Anayasa'ya uygun bulmuştur. Mahkeme kararında "sıkı bir disiplin ve hiyerarşik düzen gerektiren kimi mesleklerde disiplinin bozulması, kamu düzenini tehdit edici boyutlara ulaşabileceğinden bu gibi durumlarda, kamusal yarara üstünlük tanınarak ilgili meslekle sınırlı olarak sendikalaşmanın yasaklanması gerekli hale gelebilir" diyerek "telafisi güç veya imkansız zarar" gibi bir ölçüt yerine “mesleki disiplin” kavramına gönderme yapmıştır. Mahkeme’ye göre:

"[D]emokratik toplum düzeninin sürdürülmesindeki üstün kamusal yarar, sendikacıllı̆ıın disiplini etkileme potansiyelini, disiplin esasına dayanan meslekler yönünden ihmal edilebilir olmaktan çıkarmakta ve bu mesleklerde sendikacılığın yasaklanmasına haklı bir temel oluşturabilmektedir. İ̧ güvenlik, sıkı bir hiyerarşik disiplin gerektiren ve icabında şiddet kullanma yetkisi veren, kamu düzeninin tesisi bakımından hayati öneme sahip bir kamu hizmetidir. Bu hizmetin aksaması, kamu düzeni yönünden telafisi gü̧̈ ve imkânsız zararların doğmasına yol açabilir. Toplumun huzur ve güvenliğini sağlamakla yükümlü olan emniyet hizmetleri sınıfi mensupları arasındaki hiyerarşi ve disiplinin aşınması, iç güvenlik

agk, para. 17. 
hizmetinin aksamasina neden olabilecek temel etkenlerden biridir. Demokratik toplum düzeninin varlığını sürdürebilmesinin önkoşulu olan iç güvenlik hizmetlerinin aksamadan ve sağllklı bir şekilde yerine getirilmesinin temini bakımından bu hizmetin asli unsuru olan emniyet hizmetleri sinıfi mensuplarının sendika kurmasının yasaklanması, kanun koyucunun takdir yetkisi kapsamında başvurabileceği tedbirler arasındadır. ${ }^{, 99}$

AYM'nin bu kararı Kamu Görevlileri Sendikaları ve Toplu Sözleşme Kanunu ile sendika kurması ve sendikaya üye olması yasaklanan Türk Silahlı Kuvvetleri, Milli İstihbarat Teşkilatı, Jandarma Genel Komutanlığı ve Sahil Güvenlik Komutanlı̆̆ı'nda görevli subay, sözleşmeli subay, astsubay, sözleşmeli astsubay, uzman jandarma, uzman erbaş, sözleşmeli erbaş ve sözleşmeli erler ile ceza infaz kurumlarında çalışanlar gibi bazı kamu görevlileri ile ilgili olası başvurularda benzer bir yaklaşım sergilenebileceğini göstermektedir. AYM anılan kararında geçmişte yürürlükte olan "emniyet teşkilatında çalışan diğer hizmet sınıflarına dahil personel" düzenlemesini ise "iç güvenlik hizmetlerinin asli unsuru olmayan ve kimi teknik ve lojistik hizmetleri yürütmekle sınırlı görev icra eden sivil personelin çalışma disiplini üzerinde yaratacağı etkinin, bunların sendika kurma hakkından yoksun bırakılmalarını gerekli kılmadığı" gerekçesiyle iptal etmiştir. ${ }^{100}$ Benzer yaklaşım başka bir kararda, "Milli Savunma Bakanlığı ile Türk Silahlı Kuvvetleri kadrolarında (Jandarma Genel Komutanlığı ve Sahil Güvenlik Komutanlığı dahil) çalışan sivil memurlar ve kamu görevlileri" bakımından da sergilenmiştir. ${ }^{101}$

AYM'nin yukarıda belirtilen kararlarından TSK ve genel kolluk mensubu olup bu kurumların asli görevini yerine getiren kişiler bakımından sendika yasağının Anayasa'ya uygun bulunduğu, bu kurumlarda tali görevler yerine getiren kişiler açısından ise Anayasa'ya aykırı görüldüğü ortaya çıkmaktadır. AYM'nin sendikalar bakımından ortaya koyduğu bu yaklaşımın dernekler ve vakıflar bakımından da sergilenip sergilenmeyeceği henüz belirsizdir. Ancak sendikalara ilişkin dile getirilen kaygıların dernek veya vakıf biçimindeki örgütler açısından da ileri sürülmesi ve benzer bir yaklaşımın dernekler ve vakıflar bakımından da ortaya konulması olası gözükmektedir.

\section{Kamu Tüzel Kișileri ve Örgütlenme Özgürlüğü}

"Örgüt" kavramının yukarıda da belirtildiği gibi "kişilerin serbest iradeleriyle kurulan, ortak bir amaç için bir araya gelen kişiler topluluğu” olarak tanımlanması mümkündür. ${ }^{102} \mathrm{Bu}$ tanımda yer verilen irade unsurunun özel hukuk tüzel kişiliğine sahip toplulukları, kamu tüzel kişiliğine sahip topluluklardan ayıran en temel ölçü olduğu kabul edilmektedir. ${ }^{103}$ Kamu tüzel kişileri ise, kamu hukuku tasarruflarıyla

\footnotetext{
99 AYM, E. 2013/130, K. 2014/18, 29.01.2014.

100 agk.

101 AYM, E. 2013/21, K. 2013/57, 10.04.2013.

102 AYM, Hüseyin Demirdizen Kararl, B. No: 2014/11286, 21.09.2016, para. 35.

103 AïHM, Le Compte, Van Leuven and De Meyere v. Belgium, Appl. No: 6878/75, 7238/75, 23.06.1981, para. 43; Barthold v. Germany, Appl. No: 8734/79, 25.03.1985, para. 61; Sigurdur Sigurjonsson v. Iceland, Appl. No: 16130/90, 30.06.1993, para. 31.
} 
kurlup sone eren, üyelikleri isteğe bağlı olmayıp, zorunlu sayılan, yönetimi ve denetimi kamu güçleri tarafından sağlanan, kamu hizmeti görüp kamu yararına çalışan ve kamu erkine sahip kılınan tüzel kişiler olarak tanımlanabilir. ${ }^{104}$ Örgütlenme özgürlüğünün öznesi olan bir örgütün kural olarak kamu tüzel kişisi sıfatı taşımaması gerekmektedir. Ancak bir örgütün örgütlenme özgürlüğünden yararlanabilmesi için mutlaka özel hukuk tüzel kişisi olması da gerekmemektedir. Bu noktada yasalarda kamu tüzel kişisi olarak tanınmış olsa da belirli ölçütler bakımından ilgili kurumun örgütlenme özgürlüğünün bir öznesi olduğunun kabulü mümkündür. Bu konuda $a$ priori bir engelin bulunmadığı söylenebilir. ${ }^{105}$

AİHM bu noktada bir örgütün özel hukuk veya kamu hukuku yönünün hangisinin ağır bastığına odaklanmaktadır. ${ }^{106}$ Tüzel kişiliği haiz bir "örgüt" hükümete bağlı olmadığı ve tamamen bağımsız bir faaliyet yürütebildiği sürece örgütlenme özgürlügünün öznesi kabul edilebilir. Nitekim tüzüğü ve tüzügünün uygulanması kamu denetimi altında olan ve üyeliğin zorunlu tutulduğu ancak başkanını üyelerin seçtiği bir örgüt, örgütlenme özgürlüğünün öznesi kabul edilebilmiştir. ${ }^{107}$ Buna karşın, kuruluşu bir kanuna dayanan, idarenin bir parçası kabul edilen kamu tüzel kişiliğini haiz meslek kuruluşları, ${ }^{108}$ söz konusu mesleği yürüten kişilerin mevcut meslek örgütü dışında başka bir örgüte üye olmaları yasaklanmadığı sürece ${ }^{109}$ örgütlenme özgürlüğünün öznesi kabul edilmeyebilmektedir. ${ }^{110}$

Örgütlenme özgürlüğünden yararlanabilecek örgütlenme biçimleri bakımından gündeme gelen temel konulardan birisi kamu kurumu niteliğindeki meslek kuruluşlarının niteliğidir. Anayasa'nın 135. maddesi kamu kurumu niteliğindeki meslek kuruluşlarını "belli bir mesleğe mensup olanların müşterek ihtiyaçlarını karşılamak, mesleki faaliyetlerini kolaylaştırmak, mesleğin genel menfaatlere uygun olarak gelişmesini sağlamak, meslek mensuplarının birbirleri ile ve halk ile olan ilişkilerinde dürüstlügü ve güveni hakim kılmak üzere meslek disiplini ve ahlâkını korumak maksadı ile kanunla kurulan ve organları kendi üyeleri tarafindan kanunda gösterilen usullere göre yargı gözetimi altında, gizli oyla seçilen kamu tüzelkişilikleri” olarak tanımlamıştır. Meslek kuruluşlarının, kamu kurumu niteliğinde düzenlenmesine rağmen örgütlenme özgürlüğünün birer öznesi olarak kabul edilmesi mümkündür. Bu noktada belirleyici olan söz konusu "örgütün" işleyişinin devletten bağımsız olmasıdır. ${ }^{111}$ AİHM geçmişte kanunla kurulmuş, kamu tüzel kişiliğini haiz kabul edilen, doktorların üye olmak zorunda olduğu, düzenleyici işlem yapma yetkisine

\footnotetext{
104 Rona Serozan, Medeni Hukuk: Genel Bölüm, Kişiler Hukuku, s. 498.

105 Tomuschat, s. 497.

106 Van Dijk; Van Hoof; Van Rijn; Zwaak, s. 828.

107 AİHM, Chassagnou and Others v. France, Appl. No: 25088/94, 28331/95, 28443/95, 29.04.1999, para. 97-101.

108 AïHM, Le Compte, Van Leuven and De Meyere v. Belgium, Appl. Nos. 6878/75 and 7238/75, 23.06.1981, para 63-65.

109 AìHM, Albert and Le Compte v. Belgium, Appl. Nos. 7299/75 and 7496/76, 10.02.1983, para. 44.

110 Rainey; Wicks; Ovey, s. 474.

111 Akbulut, s. 397.
} 
sahip olan Belçika Tıp Örgütü’nün örgütlenme özgürlüğünden yararlanamayacağını kabul etmiştir. ${ }^{12}$ Ancak kararda belirleyici olan bu kuruluşun organlarının çoğunun idare tarafından atanmış olmasıdır. Türkiye'de ise Anayasa'nın 135. maddesine göre kanunla kurulan kamu kurumu niteliğindeki meslek kuruluşlarının organları tamamen üyeleri tarafindan seçilmektedir. Dolayısıyla bu kuruluşların da örgütlenme özgürlüğünün birer öznesi olduğunun kabulü gerekir. AİHM de, yönetim kurulunun büyük çoğunluğunun seçimle belirlenen ve kamu görevlilerinin üye olmasının zorunlu tutulmadığı örgütlenmeleri bu kapsamda değerlendirmektedir. ${ }^{113}$ Dolayısıyla kamu kurumu niteliğindeki meslek örgütlerinin örgütlenme özgürlüğünden yararlanabilecek bir kamu tüzel kişisi olduğunda kuşku bulunmamaktadır.

AYM de AİHM ile benzer ölçütler üzerinden değerlendirme yapmaktadır. Mahkeme, kanunla kurulmuş olup olmama, üyeliğin zorunlu olup olmaması, idari yetkiler kullanıp kullanılmaması, düzenleme ve disiplin yaptırımı uygulama yetkisinin mevcut olup olmadığı gibi ölçütleri dikkate almaktadır. Üyelerinin serbest iradesi ile kurulmamış, kanunla kurulmuş, işleyişi kanunla belirlenmiş bir kurum kamu kurumu niteliğindedir. ${ }^{114}$ Buna göre "kamu iradesi bulunmayan toplulukların örgütlenme özgürlüğü temelinde, kamu gücüne karşı menfaatlerinin koruması için dayanışma ve toplu ifade gücünden faydalanması söz konusu olmaktadır.”115

Benzer ölçütler kullanılmasına rağmen, AYM'ye göre Anayasa'nın 135. maddesinde özel olarak düzenlenen kamu kurumu niteliğindeki meslek kuruluşları Anayasa'nın 33. maddesi kapsamında değerlendirilmesi mümkün değildir. ${ }^{116}$ AYM geçmişte şu ifadeler ile bu tür örgütlenmelerin kamu tüzel kişisi biçimindeki hukuki statülerinin tartışmasız olduğunu kabul etmiştir: ${ }^{117}$

"Meslek kuruluşlarının amaçları belirlenerek, dolayısıyla faaliyet alanları sınırlandırılmış, bunların birer kamu tüzelkişisi olduğu açıklı̆ga kavuşturulmuş; organlarının seçimi yargı gözetimine tabi kılınmış, amaç dışı faaliyet göstermeleri, siyasetle uğraşmaları; siyasi partiler, sendikalar ve derneklerle ortak hareket etmeleri yasaklanmış; devletin bu kuruluşlar üzerindeki idari ve mali denetim hakkı açıkça belirlenmiş, amaç dışı faaliyet yaptırıma bağlanmış, Devlet ve Millet hayatını tehdit edici bir takım faaliyetlerin önlenmesi bakımından, gecikmesinde sakınca bulunan hallerde, en büyük mülki amire kuruluş organlarını geçici olarak görevden uzaklaştırma yetkisi tanınmıştır, denmek suretiyle meslek kuruluşlarının hukuki statüleri tereddütsüz belirlenmiştir."

AYM'nin bu kararına rağmen Anayasa'nın 135. maddesindeki mevcut düzenleme kamu kurumu niteliğindeki meslek kuruluşlarının örgütlenme özgürlüğünden

\footnotetext{
112 AİHM, Le Compte, Van Leuven and De Meyere v. Belgium, Appl. No: 6878/75, 7238/75, 23.06.1981, para. 64.

113 AİHM, Radio France and Others v. France, Appl. No: 53984/00, 23.09.2003, s. 20-22.

114 AYM, E. 1985/7, K. 1985/22, 28.11.1985.

115 AYM, Hüseyin Demirdizen Kararl, B. No: 2014/11286, 21.09.2016, para. 35.

116 AYM, E. 1995/39, K. 1995/45, 19.09.1995.

117 AYM, E. 1984/12, K. 1985/6, 01.03.1985.
} 
yararlanamayacağı anlamına gelmemektedir. Kamu kurumu niteliğindeki meslek kuruluşları, kamu kurumu gibi görev ve yetkiler ile donatılmış olsa da, birer kamu kurumu niteliğinde kabul edilmemektedir. Ayrıca Anayasa'nın 135. maddesinde ayr1 bir düzenleme yapılmış olması da bu kuruluşları örgütlenme özgürlüğünün öznesi olmaktan çıkarmamaktadır. Nasıl ki siyasi partiler ve sendikalar farklı maddelerde düzenlenmiş olsa da örgütlenme özgürlüğünün öznesi olarak kabul ediliyorsa, meslek kuruluşları bakımından da aynı durumun geçerli kabul edilmesinin önünde bir engel bulunmamaktadır. AİHM ve AYM kararlarında ortaya çıkan ölçütler çerçevesinde Anayasa'nın 33. maddesi ile 135. maddesi birlikte yorumlanmalı ve kamu kurumu niteliğindeki meslek kuruluşları da 33. madde kapsamında ortaya çıkan bazı ilke ve güvencelerden yararlanabilecek kuruluşlar olarak kabul edilmelidir. Nitekim günümüzde öğretide de kamu kurumu niteliğindeki meslek kuruluşlarının örgütlenme özgürlüğünün güvencesi altında olduğu kabul edilmeye başlanmıştır. ${ }^{118}$

AYM yakın zaman önce meslek kuruluşlarının statüsü ile ilgili katı yaklaşımında kısmen değişikliğe gitmiştir. Mahkeme meslek kuruluşlarının kamu kurumu niteliğinde olsa da sivil toplum örgütlerinin sahip olduğu bazı haklardan yararlanabileceğini kabul etmiştir. ${ }^{19}$ Mahkeme'ye göre, “Anayasa'nın 135. maddesinde, meslek kuruluşlarının karar ve yönetim organlarının seçimle göreve gelmesinin öngörülmesi, devletin idari ve mali denetimine tabi olduklarının belirtilmesi ve sorumlu organlarının görevlerine ancak yarg1 kararıyla son verilebileceğinin kurala bağlanması, bu idarelerin özerkliğine işaret etmektedir." ${ }^{\prime 20} \mathrm{Bu}$ yaklaşımın olası sonucu bu tür kuruluşların faaliyetlerinde daha fazla özerkliğe sahip olması ve organlarının oluşumu ve görevden alınmasında demokratik hukuk devleti ilkesinin daha fazla uygulama alanı bulmasıdır. Bireysel başvuru usulü kapsamında verilen bir başka kararda ise kamu kurumu niteliğindeki bir meslek kuruluşuna üye olma zorunluluğu olmayan ancak ihtiyari olarak üye olmuş olan başvurucunun şikâyeti sendika hakkı kapsamında değerlendirilmiştir. ${ }^{121} \mathrm{Bu}$ kararlara rağmen kamu kurumu niteliğindeki meslek kuruluşlarının halen tam anlamıyla örgütlenme özgürlüğünün öznesi olarak kabul edilmediğini belirtmek gerekir.

\section{Kamu Görevlilerinin Dernek ve Vakıf Kurucusu Olma Hakkı}

\section{A. Genel Olarak}

Örgütlenme özgürlüğü öncelikle örgüt kurma özgürlüğünü içermektedir. AİHS'nin 11. maddesinde bu tür bir hakka açıça sadece sendikalar bakımından değinilmiş olsa da bu durum diğer örgütlerin bu haktan yararlanamayacakları anlamına

\footnotetext{
18 Akbulut, s. 398-399.

119 AYM, E. 2012/12, K. 2013/7, 10.01.2013.

120 AYM, E. 2011/150, K. 2013/30, 14.02.2013.

121 AYM, Hüseyin Demirdizen Kararl, B. No: 2014/11286, 21.09.2016, para. 46.
} 
gelmemektedir. ${ }^{122}$ Anayasa'nın 33. maddesi “dernek kurma hakkı" başlığını taşımakla birlikte, son fikrasında yer alan "Bu madde hükümleri vakıflarla ilgili olarak da uygulanır." ifadesi ile derneklerle ilgili düzenlemenin vakıflar için de geçerli olduğu kabul edilmiştir. ${ }^{123} \mathrm{Bu}$ durum, 33. madde madde metnindeki "dernek" ifadesinin AİHS'nin 11. maddesindeki "örgüt”" ifadesi ile tam anlamıla paralel olmadığı ancak çalışma açısından dernek ve vakıfların ikisini de kapsadığı anlamına gelmektedir. ${ }^{124}$ $\mathrm{Bu}$ açıdan Anayasa ve AİHS arasında bir örtüşme söz konusudur.

Avrupa Konseyi'nin CM/Rec(2007)14 sayılı Tavsiye Kararı'na göre üye temelli bir örgütün kuruluşu için en az iki kişinin varlığ yeterli kabul edilmelidir. ${ }^{125}$ Tüzel kişilik kazanmak için daha yüksek bir sayının öngörülmesi mümkündür ancak bu sayının kişileri örgüt kurmaktan caydıracak bir yükseklikte kabul edilmemesi gerekmektedir. ${ }^{126}$ Türk hukukunda TMK'nın 56. maddesi ve Dernekler Kanunu'nun 2. maddesine göre dernekler yedi gerçek veya tüzel kişinin bir araya gelmesi ile kurulabilmektedir. Mevcut sayı koşulu çok yüksek olmamakla birlikte Avrupa Konseyi Tavsiye Kararı'nda yer alan “en az iki kişi” koşulu ile örtüşmemektedir. ${ }^{127}$

Vakıflar, TMK'nın 101. maddesine göre "gerçek veya tüzel kişilerin yeterli mal ve hakları belirli ve sürekli bir amaca özgülemeleriyle oluşan tüzel kişiliğe sahip mal topluluğu" olarak tanımlandığı için üye temelli örgütler değildir. Bu nedenle kurucu sayısı ile ilgili herhangi bir sınırlama bulunmamaktadır. Vakıfların kurulabilmesi için Vakıflar Kanunu'nun 5. maddesine göre her yıl Vakıflar Meclisi tarafından belirlenecek asgari malvarlığını vakfa özgülemesi yeterlidir. Burada dikkat edilmesi gereken husus özgülenecek malvarlığının vakıf kurulmasını olanaksız hale getirmeyecek olmasıdır. ${ }^{128}$

Örgütlerin kuruluşunda gündeme gelen diğer bir konu tüzük vb. belgelerdir. Örgütlenme özgürlüğü örgütlerin kendi iç kurallarını düzenleme hakkını da

122 Tomuschat, s. 498; Van Dijk; Van Hoof; Van Rijn; Zwaak, s. 831.

123 AYM, E. 2005/14, K. 2008/92, 17.04.2008; E. 2008/22, K. 2010/82, 17.06.2010.

124 Akbulut, s. 398.

125 Bakanlar Konseyi'nin Avrupa'daki hükümet-dışı örgütlerin hukuki statüsüne ilişkin üye devletlere CM/Rec (2007)14 say1l Tavsiye Karar1 (Recommendation CM/Rec(2007)14 of the Committee of Ministers to member states on the legal status of non-governmental organisations in Europe), para 16-17, https://search.coe.int/cm/Pages/result_details. aspx?ObjectID $=09000016805 \mathrm{~d} 534 \mathrm{~d}$ (erişim: 01.05.2018)

126 Kiai, para 54.

127 Dernekler Kanunu'nda kuruluşu için gerçek veya tüzel en az üç kişinin bir araya gelmesinin yeterli olabileceğine dair bir değişiklik örgütlenme özgürlüğünün kullanımının kolaylaştırılması bakımından daha uygun gözükmektedir. Ancak kurucu sayısı ile ilgili bu tür bir düzenleme yapılsa dahi TMK'nın ilk genel kurul toplantısının tescilden itibaren altı ay içinde yapılmasını ve zorunlu organların oluşturulmasını mecbur tutan 62. maddesi sorun oluşturmaktadır. TMK'nın 84 . ve 86 . maddelerine göre derneklerin zorunlu organları olan yönetim ve denetim kurullarının oluşturulabilmesi için en az 16 üyeye gereksinim vardır. Dernekler kurulmalarının ardından altı ay içerisinde en az 16 üyeye ulaşmak zorundadır. Bu durumda dernek kurucu sayısında bir azaltmaya gidilmesi tek başına bir anlam ifade etmemektedir. Bu durum dernek kurucu sayısının filen 16'ya çıkması olarak görülmektedir. Bkz, Rona, Serozan, Tüzel Kişiler: Özellikle Dernekler ve Vakıflar, Filiz Kitabevi, İstanbul, 1994 s. 56.

128 Vakıflar Meclisi tarafından alınacak böyle bir karara karşı meclisin takdir yetkisinin kısıtlayacak bir hükme yasada yer verilmesi olumlu olacaktır. Ayrıca Vakıflar Meclisi tarafından alınacak kararlara yargı yolunun açık tutulması gerekmektedir. 
içermektedir. ${ }^{129}$ Devletlerin örgütlerin kuruluş aşamasında resmi bir sicile kaydolması zorunluluğu getirilmesi örgütlenme özgürlüğünün başlı başına ihlal etmemektedir. Ancak kayıt olmak isteyen bir örgütün kaydının yapılmaması da örgütlenme özgürlüğüne yönelik haklı kılınması gereken bir müdahaledir. ${ }^{130}$

Türkiye'de tüzel kişiliğe sahip olmak isteyen örgütlerin kuruluşlarında söz konusu örgüt dernek ise bir tüzüğünün veya vakıf ise bir kuruluş senedinin bulunması gerekmektedir. $\mathrm{Bu}$ belgelerde hangi hususların yer alması gerektiği mevzuatta düzenlenmesi mümkündür. Üye temelli bir örgütün tüzel kişilik kazanmak amacıyla gerçekleştirdiği başvurusunda tüzüğü, adresi, kurucuların, yöneticilerin ve yasal temsilcilerin isimlerinin sunulması yeterli görülmelidir. Üye temelli olmayan örgütler için ise belirlenen amacın yerine getirilebilmesi için sahip olunan mali kaynakların ispatlanması makul görülmektedir.

Dernekler Kanunu'nun 4. maddesine göre her derneğin bir tüzüğü bulunmalıdır ve tüzükte 4. maddede öngörülen bir dizi zorunlu unsurun yer alması gerekmektedir. ${ }^{131}$ Vakıflar üye temelli örgütlenmeler olmadıkları için kuruluşları farklı biçimde gerçekleşmektedir. Vakfin kuruluşu bir vakıf senedinin hazırlanması ile gerçekleşmektedir. TMK'nın 106. maddesine göre "Vakıf senedinde vakfın adı, amacı, bu amaca özgülenen mal ve haklar, vakfın örgütlenme ve yönetim şekli ile yerleşim yeri gösterilir.” Görüldüğü üzere vakıf senetlerinde dernek tüzükleri ile karşılaştırıldığında daha az sayıda hususun yer alması gerekmektedir.

\section{B. Dernek ve Vakıf Kurma Hakkı}

\section{Genel Olarak}

Yukarıda örgütlerin kuruluşuna ilişkin yapılan açıklamaların ardından kamu görevlilerinin dernek ve vakıf kurucusu olup olmayacağı sorusu gündeme gelmektedir. Tüzel kişiliği olan bir örgütün kurucusu olmak isteyen kişiler için belirli niteliklerin öngörülmesi olağandır ve bazı durumlarda kişilerin örgüt kurucusu olması yasaklanabilmesi mümkündür. Örneğin belirli bir suçtan yargısal bir kararla mahkûm olmuş bir kişiye bu yönde bir yasak getirilmesi mümkündür. Ancak söz konusu suçun bir kişinin örgütün kurucusu olmasının yasaklanmasını gerektirebilecek bir suç olması ve söz konusu yasağın kapsamının ve süresinin orantılı olması gerekmektedir. Süresiz ve kapsamı belirsiz bir yasak bu koşul ile aykırılık taşıyacaktır. ${ }^{132}$

129 Aldabak, s. 82.

130 Rainey; Wicks; Ovey, s. 475.

131 Dernek tüzüklerinde aranan bu zorunlu unsurlar yukarıda belirtilen gereklilikle uyumlu gözükmekle birlikte tüzüğün içeriğine dair bu kadar ayrıntılı bir düzenlemenin örgütlenme özgürlüğü ile bağdaştığını söylemek güçtür. Örgütlerin faaliyetlerinde özerk hareket edebilmesi ilkesi çerçevesinde bir dernek tüzüğünde yer alması gereken unsurların mümkün olduğunca sınırlı olarak sayılması, bu noktada örgütlerin tanımı ve unsurlarında yer alan hususlarla sınırlı bir çerçeve örgütlenme özgürlüğünün kullanımının kolaylaştırılması bakımından daha uygun gözükmektedir. Bu noktada tüzükte yer alması gereken hususların derneğin adı, adresi ve amacı ile sınırlı tutulması yeterli olacaktır.

$132 \mathrm{CM} / \operatorname{Rec}(2007) 14$, para 30 . 
Türkiye'de derneklerin kuruluşunda serbest kuruluş sistemi benimsenmiştir. ${ }^{133}$ Dernek kurabilecek kişilerle ilgili olarak Dernekler Kanunu'nun 3. maddesinin ilk fikrasında, Anayasa'nın 33. maddesine uygun olarak, "fiil ehliyetine sahip gerçek veya tüzel kişiler, önceden izin almaksızın dernek kurma hakkına sahiptir.” şeklinde bir düzenleme getirmiştir. Anayasa'nın 33. maddesinde görüldüğü gibi burada da hakkın öznesi Anayasa' da olduğu gibi “herkes”tir. Ancak maddede bir dizi koşul da öngörülmüştür. İlk koşul yukarıda belirtilen ilk fikrada yer alan fiil ehliyeti ile ilgilidir. TMK'nın 10. maddesine göre göre ayırt etme gücüne sahip olan, kısıtlanmamış ve 18 yaşını doldurmuş herkes fiil ehliyetine sahiptir. TMK'nın 13. maddesi ayırt etme gücü olmama haline örnek olarak yaş küçüklüğünü, akıl hastalığını, akıl zayıflı̆̆ını, sarhoşluğu veya bunlardan birine benzer nedenlerle akla uygun davranma yeteneğinden yoksun olmama olarak tarif etmiştir. Belirtilen nitelikler kamu görevlilerinin kamu görevlisi olabilmek için taşımaları gereken nitelikler olduğu için bu konuda mevzuat bir sorun oluşturmamaktadır.

Bir önceki 2908 say1lı Dernekler Kanunu134 4. maddesi ile, Yüksek Mahkeme üyeleri, hâkim ve savcılar; Sayıştay meslek mensupları ile savcı ve yardımcıları, mülkî idare amirliği hizmetlerine dahil kadrolarda çalışanlar, Türk Silahlı Kuvvetleri ile genel ve özel kolluk kuvvetleri mensupları, resmi ve özel ilkokul, ortaokul, lise veya dengi okullar öğretmen ve yöneticileri, Milli Eğitim Bakanlığı merkez ve iller kuruluşunda çalışan öğretmenler ile diğer personeli ve özel kanunlarında dernek kuramayacakları belirtilen kamu hizmeti görevlileri ile resmi ve özel ortaokul ve ortaöğretim öğrencilerinin dernek kuramayacakları düzenlenmiştir. $\mathrm{Bu}$ düzenleme başlı başına ölçüsüz bir düzenleme niteliğindedir. ${ }^{135}$ Maddede 2003 yılında yapılan değişiklikle yalnızca "Türk Silâhlı Kuvvetleri ile genel ve özel kolluk kuvvetleri mensupları ve özel kanunlarında dernek kuramayacakları belirtilen memur statüsündeki kamu hizmeti görevlileri" dernek kurma hakkından yoksun bırakılmıştır. ${ }^{136} 5253$ sayılı Dernekler Kanunu'nun 3. maddesi ise önceki düzenlemelerin aksine AİHS ve Anayasa'ya paralel biçimde "Türk Silâhlı Kuvvetleri ve kolluk kuvvetleri mensupları ile kamu kurum ve kuruluşlarının memur statüsündeki görevlileri hakkında özel kanunlarında getirilen kısıtlamalar saklıdır.” şeklindeki bir ifadeye yer vermiş ve genel bir yasak içermemiştir.

Vakıflar açısından dernekler de olduğu gibi serbest kuruluş sistemi değil, tescil sistemi öngörülmüştür. ${ }^{137}$ Dernek kurucuları için mevzuatta öngörülen fiil ehliyeti koşulu vakıflar bakımından da geçerlidir. Çalışmanın kapsamına girebilecek vakıflar ölüme bağlı tasarruf yoluyla değil, vakıf senedi ile kurulabilecek vakıflar

133 Dural; Öğüz, s. 235; Oğuzman; Seliçi; Özdemir, s. 254.

134 Bkz, 07.10.1983 tarihli ve 18184 sayılı Resmi Gazete.

135 Serozan, Tüzel Kişiler: Özellikle Dernekler ve Vakıflar, s. 55.

136 Bkz, 4963 sayılı Çeşitli Kanunlarda Değişiklik Yapılmasına İlişkin Kanun, 11. madde, 07.08.2003 tarihli ve 25192 sayılı Resmi Gazete.

137 Dural; Öğüz, s. 235; Oğuzman; Seliçi; Özdemir, s. 255. 
olduğu için bu vakıfların kuruluş usulüne bakılması gerekmektedir. Buna göre vakıf kurucusu olmak için öncelikle fiil ehliyetine sahip olmak gerekmektedir. ${ }^{138}$ Vakıflara ilişkin TMK ve Vakıflar Kanunu'nda da kamu görevlilerine ilişkin özel bir koşul öngörülmediği görülmektedir.

Sonuç olarak, Anayasa, TMK, Vakıflar Kanunu ve Dernekler Kanunu metninden kamu görevlilerine dönük bir kategorik yasaklama olmadığı ortaya çıkmaktadır. TMK, Vakıflar Kanunu ve Dernekler Kanunu'nda kamu görevlilerinin dernek kurma hakkına bir sınırlama getirilmemiş olsa da bir dizi kanunda bazı kamu görevlileri için sınırlama getirildiği görülmektedir. ${ }^{139}$ Kamu görevlilerinin dernek ve vakıf kurma hakkına getirilen sınırlamalar aşağıda TSK ve genel kolluk mensupları ve bu kişiler dışında kalan kamu görevlileri bakımından ayrı ayrı değerlendirilecektir. Ancak yargı organları mensupları çalışmanın sınırları kapsamı dışında tutulmuştur.

\section{Türk Silahlı Kuvvetleri Mensupları}

TSK mensupları açısından dernek veya vakıf kurma hakkı bağlamında mevzuata bakıldığında 211 sayılı Türk Silahlı Kuvvetleri İç Hizmet Kanunu'nun 43/1 maddesinde bu kişilere siyasi faaliyet yasağı getirdiği görülmektedir. Bu yasak siyasi parti ve derneklere üyeliği ve bunlar bünyesinde diğer her türlü faaliyeti yasaklamaktadır. Kanunda her ne kadar siyasi dernek ifadesi kullanılmışsa da söz konusu ifadenin kapsamı Türk hukukunda "siyasi dernek" biçiminde ayrı bir dernek türü bulunmadığı için muğlaktır. Başka bir deyişle bir derneğin "siyasi” olup olmadığına TSK'nın kendisi karar verecektir ve bu tür bir tespitte bulunulması halinde ilgili TSK mensubu hakkında bazı disiplin yaptırımları uygulanabilecektir.

211 sayılı Kanun'un 43/2 maddesine göre TSK mensuplarının Milli Savunma Bakanlığı tarafından adları yayınlanmış ve siyasi olmadığı kabul edilmiş derneklere üye olmaları ve spor kulüplerinin faal olmayan üyeliklerine girmeleri mümkündür. ${ }^{140}$ Bu durumda dahi üyeliğin Milli Savunma Bakanlığı'na bildirilmesi gerekmektedir. Görüldüğü gibi TSK mensuplarının Milli Savunma Bakanlığı tarafindan adları yayınlanmayan derneklere üyeliği yasaklanmış olmakla birlikte dernek kurucusu olmaları açıkça yasaklanmamıştır. Dernekler Kanunu da ise yalnızca TSK mensuplarına özel kanunlarla getirilen kısıtlamalara gönderme yapmaktadır. Yine

\footnotetext{
138 İpek Yücer, “Gerçek Kişilerin Vakıf Kurma Ehliyeti”, Prof. Dr. Sarper Süzek'e Armağan, Cilt III, Beta Yay., İstanbul, 2011, s. 2966; Dural; Öğüz, s. 347; Oğuzman; Seliçi; Özdemir, s. 364.

139 Bazı kamu görevlilerinin dernekler ve vakıflar bağlamında örgütlenme özgürlüğüne çeşitli düzeylerde sınırlama getiren kanunlar şunlardır: 211 sayılı Türk Silahlı Kuvvetleri İç Hizmet Kanunu; 477 sayılı Disiplin Mahkemeleri Kuruluşu, Yargılama Usulü ve Disiplin Suç ve Cezaları Hakkında Kanun; 6413 sayılı Türk Silahlı Kuvvetleri Disiplin Kanunu; 3201 sayılı Emniyet Teşkilatı Kanunu; 7068 sayılı Genel Kolluk Disiplin Hükümleri Hakkında Kanun Hükmünde Kararnamenin Kabul Edilmesine Dair Kanun; 6112 sayılı Radyo ve Televizyonların Kuruluş ve Yayın Hizmetleri Hakkında Kanun; 4054 sayılı Rekabetin Korunması Hakkında Kanun; 6362 sayılı Sermaye Piyasası Kanunu; 3069 sayılı Türkiye Büyük Millet Meclisi Üyeliği ile Bağdaşmayan İşler Hakkında Kanun; 1211 sayılı Türkiye Cumhuriyet Merkez Bankası Kanunu; 5411 sayılı bankacılık Kanunu ve 2547 sayılı Yükseköğretim Kanunu; 4734 sayılı Kamu İhale Kanunu.

$140 \quad$ 01.05.2018 tarihi itibariyle TSK mensuplarının hangi derneklere üye olabileceğine dair bir listeye Genelkurmay Başkanlığı (http://www.tsk.tr) veya Milli Savunma Bakanlığı'nın (http://www.msb.gov.tr) resmi internet sitelerinden ulaşılamamıştır.
} 
de bu iki hüküm birlikte değerlendirildiğinde TSK mensuplarının dernek kurucu olabilecekleri şeklinde bir sonuca ulaşmak mümkün gözükmemektedir. Bir derneğin kurucusu olmak aynı zamanda o derneğe üyelik gerektirdiği için üyeliğin yasaklandığı durumda kurucu olunamayacağı bu durumun mantıksal sonucudur.

211 sayılı Kanun'un 43/3 maddesine göre TSK mensuplarının yalnızca kendi kıta, karargâh ve kurumları içinde amatör askeri spor kulüpleri kurabilmesi ve bu kulüplerde faaliyette bulunabilmesi mümkün gözükmektedir. Bu kulüplerin kurulması için de bu kez Genelkurmay Başkanlığı'ndan izin alınması gerekmektedir. Görüldüğü gibi TSK mensupları yalnızca belirtilen amatör spor kulüplerinin kurucusu olabilmektedir ve başka bir amaç taşıyan bir derneğin kurucusu olması mümkün değildir.

Son olarak 211 say1lı Kanun'un 43/4 maddesinde ise TSK mensuplarının kanunla kurulan meslek kuruluşlarına üyeliliği ve organlarında görev alması da yasaklanmıştır. Anayasa'nın 135. maddesi kapsamında kurulmuş olan kamu kurumu niteliğindeki meslek kuruluşlarına üyeliğin de örgütlenme özgürlüğünün bir parçası olduğu düşünüldüğünde bu tür bir kısıtlamanın da üye olma hakkı kapsamında getirilen bir kısıtlama olarak değerlendirilmesi mümkündür.

Öte yandan bu düzenlemelerle TSK mensuplarına Milli Savunma Bakanlığı tarafından adları yayınlanan dernekler dışındaki derneklere üyelik yasaklanmış olsa da 6413 sayılı Türk Silahlı Kuvvetleri Disiplin Kanunu'nun 19. maddesinin $1 / \mathrm{k}$ bendi dernek üyelikleri ile spor kulüplerinin faal üyeliklerine izin almaksızın girmeyi disiplin suçu olarak düzenlemiştir. Milli Savunma Bakanlı̆̆ı'nca adları yayınlanan derneklere üyelik izne tabi tutulmamıştır. İzne tabi tutulan tek durum TSK mensuplarınca kendi kıta, karargâh ve kurumları içinde amatör askeri spor kulüpleri kurmaları durumudur. Bunun dışında derneklere üyelik izne değil bildirime tabi tutulmuştur. Dolayısıyla 6413 sayılı Kanun dernek kurmaya yönelik bir disiplin suçu öngörmemiştir. Bu tür bir fiil yasaklanmış olsa da herhangi bir yaptırma bağlanmamış gözükmektedir. Suç ve cezaların kanuniliği ilkesinin disiplin suçları bakımından uygulanabilir olduğu dikkate alındığında dernek kurucusu olan TSK mensuplarına disiplin cezası verilemeyeceği ortaya çıkmaktadır.

Mevzuatta kamu görevlileri açısından dernekler yanında vakıf kurucusu olma ile ilgili de bir dizi sınırlama mevcuttur. TSK mensupları açısından bu yönde yasal bir sınırlama öngörülmemiştir. Bu durumun nedeni vakıfların üye temelli olamayan örgütler olarak görülmesi olabilir. 6413 sayılı Kanun'un 19/1-k maddesine göre yalnızca izin alınmaksızın vakıf üyesi olmak yasaklanmıştır. 477 sayılı Disiplin Mahkemeleri Kuruluşu, Yargılama Usulü ve Disiplin Suç ve Cezaları Hakkında Kanun'da derneklerin tersine vakıf üyeliği veya kurucusu olmak yasaklanmamıştır. Mevzuatta vakıf kurucusu olmanın yasaklandığına dair açık bir düzenleme olmaması ve vakıflar açısından kurucu olmanın üye olmayı gerektirmediği düşünüldüğünde 
TSK mensupları açısından vakıf kurucusu olma yönünde bir yasak olmadığı ortaya çıkmaktadır.

\section{Genel Kolluk Mensupları}

Kuruluş kanunlarına göre Emniyet Genel Müdürlüğü, Sahil Güvenlik Komutanlığı ve Jandarma Genel Komutanlığı mensupları genel kolluk kuvveti olarak adlandırılmıştır. ${ }^{141}$ Çalışmada kolluk mensupları kavramı bu üç kurumda görev yapan kamu görevlilerini nitelemek için kullanılmaktadır. Emniyet görevlileri açısından 3201 sayılı Emniyet Teşkilatı Kanunu Ek Madde 11'e göre "Emniyet Teşkilatı mensupları ile çarşı ve mahalle bekçileri dernek kurucusu... olamazlar.” Buna benzer düzenlemeler 2692 sayılı Sahil Güvenlik Komutanlığı Kanunu ve 2803 sayılı Jandarma Teşkilat, Görev ve Yetkileri Kanunu'nda yer almamaktadır. Ancak 7068 sayılı Genel Kolluk Disiplin Hükümleri Hakkında Kanun Hükmünde Kararnamenin Kabul Edilmesine Dair Kanun bu üç kurumda görev yapan kamu görevlilerini aynı disiplin hükümlerine tabi tutmuştur. Anılan Kanun'un 8/6-ff maddesinde dernek kurmak disiplin suçu olarak düzenlenmiştir. $\mathrm{Bu}$ düzenlemeden dernek kurmanın genel kolluk mensuplarının tümü için yasaklandığı sonucunu çıkarmak mümkündür. $\mathrm{Bu}$ sınırlamaya uyulmaması durumunda disiplin cezası verileceği düzenlenmiştir. Söz konusu ceza 7068 sayılı Kanun'un 8/6-ff maddesine göre meslekten çıkarma cezası gibi oldukça ağır bir cezadır.

3201 sayılı Emniyet Teşkilatı Kanunu'nun Ek 11. maddesine göre “Emniyet Teşkilatı mensupları ile çarşı ve mahalle bekçilerinin 17/2/1926 tarihli ve 743 sayılı Türk Kanunu Medenisi kapsamındaki vakıfların kurucusu olabilmeleri ile bu vakıfların yönetim organlarında görev alabilmeleri Emniyet Genel Müdürünün teklifiyle İçişleri Bakanının iznine bağlıdır." Bu sınırlamaya uyulmaması durumunda derneklerle ilgili olduğu gibi burada da 7068 sayılı Kanun ile meslekten çıkarma biçiminde bir disiplin cezası verileceği düzenlenmiştir. ${ }^{142}$ Görüldüğü üzere TSK açısından bir yasak bulunmamasına rağmen Emniyet mensupları açısından bir açık yasak söz konusudur. Bu durum kanun koyucunun konuya tutarlı bir şekilde yaklaşmadığının açık bir göstergesidir.

Geçmişte TSK mensubu olarak kabul edilen ve TSK mensuplarının tabi olduğu disiplin hükümlerine tabi olan Jandarma Genel Komutanlığı ve Sahil Güvenlik Komutanlığı personeli 7068 sayılı Kanun’un 1. maddesi ile Emniyet Genel Müdürlüğü personelinin tabi olduğu disiplin hükümlerine tabi olmuştur. Bu sebeple yukarıda Emniyet mensupları bakımından dernek kurucusu olma bağlamında ortaya çıkan

141 Bkz, 2692 sayılı Sahil Güvenlik Komutanlığı Kanunu (09.07.1982 tarihli ve 17753 sayılı Resmi Gazete), 2. madde; 2803 sayılı Jandarma Teşkilat, Görev ve Yetkileri Kanunu (12.03.1983 tarihli ve 17985 sayılı Resmi Gazete), 3. madde; 3201 sayılı Emniyet Teşkilatı Kanunu (12.06.1937 tarihli ve 3629 sayılı Resmi Gazete).

142 Bkz, 7068 sayılı Genel Kolluk Disiplin Hükümleri Hakkında Kanun Hükmünde Kararnamenin Kabul Edilmesine Dair Kanun'un 8/6-gg maddesi. 
durum bu iki komutanlık mensupları için de geçerlidir. Diğer yandan bu iki kurum mensuplarının özel kanunlarında vakıf kurucusu olmaya dair bir hüküm olmaması ve 7068 sayılı Kanun'da vakıf kurucu olmanın bütünüyle yasaklanması karşısında bu kurum mensuplarının İçişleri Bakanlı̆̆ı'nın izniyle dahi olsa vakıf kurucusu olamayacakları sonucu ortaya çıkmaktadır.

\section{Diğer Kamu Görevlileri}

TSK ve genel kolluk mensupları dışında diğer kamu görevlilerinin de örgütlenme hakkına sınırlamalar getirilmiştir. Sayılan iki grup kamu görevlisine belirli ölçülerde sınırlama getirilmesi hukuken mümkün ise de geri kalan kamu görevlileri bakımından sınırlama getirilmesi örgütlenme özgürlüğünün ihlalini oluşturmaktadır. ${ }^{143}$ Konuya ilişkin temel düzenleme olana 657 sayılı Devlet Memurları Kanunu'nun 7. maddesi şöyledir:

"Devlet memurlarl her durumda Devletin menfaatlerini korumak mecburiyetindedirler.

Türkiye Cumhuriyeti Anayasasına ve kanunlarına aykırı olan, memleketin bağımsızlığını ve bütünlügünü bozan Türkiye Cumhuriyetinin güvenliğini tehlikeye düşüren herhangi bir faaliyette bulunamazlar. Aynı nitelikte faaliyet gösteren herhangi bir harekete, gruplaşmaya, teşekküle veya derneğe katılamazlar, bunlara yardım edemezler."

Görüldügü gibi kamu görevlilerinin dernek veya vakıf kurucusu olmalarına dair genel bir sinırlama bulunmamaktadır. Ancak kamu görevlilerinin "Türkiye Cumhuriyeti Anayasasına ve kanunlarına aykırı olan, memleketin bağımsızlı̆ını ve bütünlügünü bozan Türkiye Cumhuriyetinin güvenliğini tehlikeye düşüren herhangi bir faaliyette" bulunan derneklerin kurucusu olması mümkün değildir. Bu düzenlemede değinilen ve tırnak içerisinde verilen faaliyetler somut bir şekilde kaleme alınmamıştır. Özellikle "memleketin bağımsızlığını ve bütünlüğünü bozan Türkiye Cumhuriyetinin güvenliğini tehlikeye düşüren" faaliyetlerin ne olduğu tamamen belirsizdir. Bu belirsizlik kamu görevlilerinin örgütlenme özgürlüğ̈nün rahatlıkla sınırlanabilmesine yol açabilecek, keyfi biçimde kullanılması mümkün olan bir yetki vermektedir. Bu nedenle kamu görevlilerinin hangi derneklere üye olamayacaklarına dair açı bir yasal düzenleme ihtiyacı göze çarpmaktadır. Yapılacak yeni düzenlemede sadece kamu görevlilerinin yerine getirdiği göreve özgülenmişs sınırlamalar getirilmelidir. Bu sınırlamalar mümkün olduğunca dar tutulmalı ve belirsizlik içermemelidir.

Yukarıda TSK ve genel kolluk mensupları dışındaki diğer kamu görevlileri için 657 sayılı Devlet Memurları Kanunu'nun 7. maddesi bağlamında dile getirilen hususlar vakıflar açısından da geçerlidir. Vakıf kurucusu olmaya ilişkin mevzuatta genel bir yasak olmamakla birlikte kamu görevlilerinin de herkes gibi Anayasa'ya ve kanunlarına aykırı olan, memleketin bağımsızlığını ve bütünlüğünü bozan Türkiye Cumhuriyetinin güvenliğini tehlikeye düşüren herhangi bir faaliyet gösterecek bir vakfin kurucusu olamayacağı görülmektedir.

143 Human Rights Committee, Lebanon, A/52/40 vol. I (1997) 53, para. 357-358. 


\section{Kamu Görevlilerine Dernek ve Vakıfların Kuruluş Amaçları Bakımından Getirilen Kısıtlamalar}

\section{Genel Olarak}

Örgütlenme özgürlüğü çerçevesinde kişiler çeşitli amaçlarla bir araya gelebilmektedir ve yukarıda da belirtildiği gibi bir araya gelişin amacı noktasında herhangi bir sınırlama mevcut değildir. ${ }^{144}$ Örgütlenme özgürlüğü bünyesinde öncelikle serbestçe örgüt kurma özgürlüğünü barındırmaktadır. Herkesin menfaatleri için topluca hareket ederek tüzel kişiliğe sahip bir örgüt kurma hakkı vardır ve bu bu hak örgütlenme özgürlüğünün en önemli görünümünü oluşturur. Serbestçe örgüt kurma hakkı olmaksızın örgütlenme özgürlüğünden yararlanılması mümkün değildir. ${ }^{145}$ Örgüt kurma hakk1 beraberinde hangi amaçlarla örgüt kurulabileceği sorusunu getirmektedir. Bu noktada devletin kurucular tarafından ileri sürülen amacın gerçekten amaçlanıp amaçlanmadığı, örgütün belirtilenden başka bir amacının olup olmadığını soyut bir şekilde değerlendirmesi mümkün değildir. Kurucular tarafından ileri sürülen amaç üzerinden değerlendirme yapılmalı, kuruluş amacından farklı bir faaliyet yapıldığı ve bu faaliyetin hukuka aykırı olduğu somut bir şekilde ortaya konulduktan sonra ilgili örgüte yaptırım uygulanması mümkündür. ${ }^{146}$

Dernekler, belirli bir amaca yönelmiş kişi toplulukları olduğu için amaç dernek tüzel kişiliğinin en önemli unsurlarından birisini oluşturmaktadır. Derneklerin kuruluş amaçlarının belirlenmesinde "dernek özerkliği" ilkesi geçerlidir ve amaç emredici kurallar dışında serbestçe belirlenebilecektir. ${ }^{147}$ TMK'nın 56. maddesinde ve Dernekler Kanunu'nun 2. maddesinde yer verilmiş tanımlardan hareketle Türkiye'de derneklerin ancak kazanç paylaşmama ve kanunlarla yasaklanmamış ortak bir amacı gerçekleştirmek amacıyla kurulabileceği görülmektedir. ${ }^{148}$

Derneklerin kuruluş amaçları bakımından bir diğer kısıtlama TMK'nın 56. maddesinde yer almıştır ve hukuka ve ahlâka aykırı amaçlarla dernek kurulması yasaklanmıştır. Hatta TMK'nın 47. maddesine göre amacı hukuka veya ahlâka aykırı olan kişi ve mal toplulukları tüzel kişilik kazanamamaktadır. Burada öngörülen hukuki yaptırımın kesin hükümsüzlük olduğu kabul edilmektedir. ${ }^{149}$ Öğretide amacı hukuka ve ahlaka aykırı olan derneğin hiç tüzel kişilik kazanmadığının kabul edilmesi gerektiği vurgulanmıştı. ${ }^{150}$ Kazanç paylaşılmasının yasaklanması, kanunla yasaklanmamış ve hukuka aykırı amaçlara yönelik göndermeler makul

\footnotetext{
144 Tomuschat, s. 495.

145 AïHM, Sidiropoulos v. Greece, Appl. No: 26695/95, 10.07.1998, para 40.

146 agk, para 46-47.

147 Serozan, Medeni Hukuk: Genel Bölüm, Kişiler Hukuku, s. 509.

148 Dural; Öğüz, s. 286.

149 Serozan, Medeni Hukuk: Genel Bölüm, Kişiler Hukuku, s. 504; Dural; Öğüz, s. 239.

150 Oğuzman; Seliçi; Özdemir, s. 311.
} 
olmakla beraber "ahlâka aykırılık" hukuken tanımlanabilir bir yasak değildir ve idare ve yarg1 organlarına, ahlâk kavramına verdikleri anlam kapsamında neredeyse sınırsız bir takdir yetkisi vermektedir. ${ }^{151}$ Öğretide de anılan düzenleme eleştirilmiş ve yasak amaçları anlatan bu tür deyimler haklı olarak her yana çekilmeye elverişli esneklikleriyle dernek kurma özgürlügünün kağıt üstünde bırakmak için biçilmiş kaftan olarak görülmüştür. ${ }^{152}$ Öğretide "ahlaka aykırı amaç" kavramına yönelik olarak "toplumsal değer yargıları açısından bir ahlak kuralına aykırı olan amaçlar" 153 veya "toplumda yerleşmiş ahlaki kurallara, diğer bir deyişle, genel ahlaka (adaba) aykırı amaç” gibi ifadelerle kavram somutlanmaya çalışılsa da söz konusu çabalar yetersiz gözükmektedir. ${ }^{154}$ İdareye ve yargı organlarına verilen bu takdir yetkisinin kullanımının, muhakkak örgütlenme özgürlügünün sınırlama rejimine uygun olması gerekmektedir ve yalnızca genel ahlaka veya değer yargılarına atıfla bir ihlale yol açacak biçimde kullanılmamalıdır.

Öte yandan "hukuka aykırı amaç" ifadesinde yer alan "hukuk" kavramı yalnızca kanunlarla sınırlı olarak anlaşılmamalıdır. ${ }^{155}$ "Hukuka aykırı amaç" yasağı ile ilgili bir dava yargı organları önüne geldiğinde, anılan maddede yer alan "hukuk" kavramı, Anayasa'nın 90. ve 138. maddeleri doğrultusunda Anayasa ve uluslararası sözleşmeleri de içerecek biçimde yorumlanmalıdır. Bu tür bir yorumla "hukuka aykırı amaç" ifadesinin örgütlenme özgürlüğünün ihlaline yol açmadan uygulanması mümkün k1lınabilecektir. Diğer yandan örgütlenme özgürlüğünün kötüye kullanımı niteliğinde değerlendirilebilecek bir amacın "hukuka aykırı amaç" olarak görülmesinin de örgütlenme özgürlüğüne aykırı bir yorum oluşturmayacağını eklemek gerekir.

Türk hukukunda TMK'nın 101. maddesinde yer alan vakıf tanımından amaç noktasında ortaya çıkan tek ölçüt "belirli ve sürekli bir amaç" ölçütüdür. Bununla birlikte aynı maddede vakfın amaçları ile ilgili bir dizi sınırlama getirilmiştir. TMK'nın 101/3 maddesine göre "Cumhuriyet'in Anayasa ile belirlenen niteliklerine ve Anayasa'nın temel ilkelerine, hukuka, ahlâka, milli birliğe ve milli menfaatlere aykırı veya belli bir ırk ya da cemaat mensuplarını desteklemek amacıyla vakıf kurulamaz." Sayılanların büyük çoğunluğu oldukça muğlak kavramlardır ve ne AİHS'nin 11. maddesinde ne de Anayasa'nın 33. maddesinde yer verilen meşru amaçlarla örtüşmektedir. "Cumhuriyet'in Anayasa ile belirlenen nitelikleri", "Anayasa'nın temel ilkeleri”, "milli birlik", "milli menfaat" kavramları hukuken

\footnotetext{
151 Bu konuda örnek bir dava için bkz, Yargitay 7. Daire, E. 2008/4109, K. 2008/5196, 25.11.2008. Lambda İstanbul Lezbiyen, Gey, Biseksüel, Travesti, Transeksüel Kadın ve Erkekler Arası Dayanışma Derneği hakkında tüzüğünde ahlaka aykırı amaçlara yer verdiği gerekçesiyle açılan davada derneğin feshine karar verilmiş, söz konusu karar Yargitay tarafindan bozulmuştur. Karar metni için bkz, Mesut Gülmez, "Dernek Özgürlüğü ve Cinsel Yönelime Dayalı Ayrımcılık Sorunu: Lambdaistanbul Davası Kararları (Karar İncelemesi)”, Çalışma ve Toplum Ekonomi ve Hukuk Dergisi, Sayı 22, 2009, s. 195-199.

152 Serozan, Tüzel Kişiler: Özellikle Dernekler ve Vakıflar, s. 58.

153 Ahmet Kılıçoğlu, Medeni Hukuk: Temel Kavramlar, Başlangıç Hükümleri, Kişiler Hukuku, Turhan Kitabevi, Ankara, 2016, s. 487.

154 Dural; Öğ̈̈z, s. 238.

155 Kılıçoğlu, s. 481.
} 
tanımlanabilir ve vakıf kurmak isteyen kişiler açısından öngörülebilir olmaktan uzak kavramlardır. Bu durum bir vakfın kuruluş aşamasında yargı organlarına vakfın tescil edilmemesi noktasında oldukça geniş bir takdir alanı bırakıldığı anlamına gelmektedir. Halbuki örgütlenme özgürlüğüne ilişkin mevzuatın gerekli açıklığa sahip olması ve örgütlenme özgürlüğünü kullanımını zorlaştırıcı ve kamu makamlarının keyfi muamelelerine izin verici nitelikte olmaması gerekmektedir. Mevzuat, davranışlarının sonuçlarını öngörmesini ve buna göre davranışlarına yön vermesini sağlayacak bir açıklıkta kaleme alınmalıdır. ${ }^{156}$

TMK'nın 101. maddesinde oldukça muğlak kavramlarla getirilmiş olan amaç bakımından sınırlamanın topyekûn kaldırılması ve yerine örgütlenme özgürlüğünün sınırlanması rejiminde gündeme gelen meşru amaçlarla sınırlı bir düzenleme yapılması daha uygun gözükmektedir. ${ }^{157}$ Aksi durumda Kanun'da yasaklanmış amaçların örgütlenme özgürlüğüne yönelik meşru amaçlar doğrultusunda ve sınırlama rejimindeki diğer ilkeler bağlamında yorumlanması büyük önem taşımaktadır.

Örgütlenme özgürlügünün kullanılma amacı bakımından ortaya çıkmış belki de tek sınır nefret söylemi olarak kabul edilen ırkçı, ayrımcı, yabancı düşmanı, savaş propagandası vs. görüşlerin savunulması amacıyla örgüt kurulması veya başka bir amaçla kurulmasına rağmen örgütlerin bu tür görüşleri savunmalarıdır. Nefret söylemi kategorik olarak ifade özgürlüğünün kapsamı dışında tutulmamıştır ancak ifade özgürlüğünün sınırlandırılması noktasında kolaylıkla gerekçe haline gelebilmektedir. $\mathrm{Bu}$ durumun altında yatan nedenlerden biri olarak Avrupa'da 2. Dünya Savaşı sırasında yaşanan Yahudilere, Romanlara ve engellilere yönelik soykırım gibi deneyimlere gönderme yapılmaktadır. ${ }^{158}$ Yine AİHM, Nazi ideolojisinin yüceltilmesi, 1rkçılık, Yahudi düşmanlığı gibi konularda örgütlenme özgürlüğünün sınırlanmasını, örgütlenme özgürlüğü ile uyumlu bulmaktadır. ${ }^{159}$

156 AïHM, Church of Scientology Moscow v. Russia, Appl. No. 18147/02, 05.04.2007, para 92.

157 Benzer şekilde, Serozan, “Türkiye'de Dernek ve Vakıf Kurmanın ve Yürütmenin Zorlukları”, s. 559.

158 Oktay Uygun, “Avrupa İnsan Haklart Sözleşmesi ve Türk Hukukunda Iffade Özgürlüğünün Sinırlarl”, Kamu Hukuku İncelemeleri, XII Levha Yay., İstanbul, 2011, s. 141.

159 AïHM, Féret v. Belgium, Appl. No: 15615/07, 16.07.2009; Vona v. Hungary, Appl. No: 35943/10, 09.07.2013. Birleşmiş Milletler Irk Ayrımcılığının Ortadan Kaldırılması Komitesi kararları için bkz, United Kingdom of Great Britain and Northern Ireland, A/48/18 (1993) 73, para 416-421; Germany, A/48/18 (1993) 81 at para 449; Canada, A/49/18 (1994) 47, para 329; Finland, A/51/18 (1996) 29, para 175; M. A. v. Italy, Comm. No. 117/1981, A/39/40 (10 April 1984) 190, para13.3. AYM de nefret söylemine ilişkin ilk kararında ırk, köken, renk veya cinsel yönelim temelinde gündeme gelebileceğini ve hoşgörüsüzlük temelinde nefreti yayan, teşvik eden, yücelten veya haklı gösteren ifadelerin cezalandırılabileceğini kabul etmiş ve hatta bunların önlenmesinin gerekli görülebileceğini belirtmiştir. Bkz, AYM, Sinem Hun Kararı, B. No: 2013/5356, B. No: 08.05.2014, para 32. AYM konuya dair verdiği ikinci kararında ise "ten rengi ve etnik köken, toplumsal cinsiyet, cinsel kimlik, cinsel yönelim, engellilik, siyasal aidiyet veya yaș kategorileri ile mülteci, göçmen, yabancı veya başka dezavantajlı gruplara yönelik nefret saikli ifadeler de nefret söylemi türlerinden kabul edilmelidir" demiştir ve nefret söyleminin kapsamını genişletmiştir. Bkz, AYM, Fetullah Gülen Kararı, B. No: 2014/12225, 14.07.2015, para 40. Bu kararlar ifade özgürlüğü bağlamında verilmiş kararlar olmasına rağmen benzer bir yaklaşımın örgütlenme özgürlüğüne ilişkin olarak da sergilenmesi olasıdır. 


\section{Türk Silahlı Kuvvetleri Mensupları}

Yukarıda olduğu gibi bu konu açısından da konu TSK mensupları, genel kolluk mensupları ve diğer kamu görevlileri açısından ayrı ayrı incelenecektir. 211 sayılı Türk Silahlı Kuvvetleri İç Hizmet Kanunu'nun 43/1 maddesi TSK mensuplarının siyasi amaçla örgütlenmesini açıkça yasaklamıştır. Daha önce üzerinde durulduğu gibi "siyasi" amaçla dernek kurma yasağı "siyasi” kelimesinin anlamının muğlaklığı nedeniyle hukuken sorunlu bir kısıtlamadır. TSK mensuplarının sadece spor amaçlı olarak dernek kurmaları mümkündür ve bu olanak da mekânsal olarak kendi kıta, karargâh ve kurumları ile sınırlıdır ve Genelkurmay Başkanlığı'nın iznine tabidir. Başka herhangi bir amaçla dernek kurucu olunması mümkün gözükmemektedir.

TSK mensuplarının vakıf kurucusu olması açıkça yasaklanmadığı için bu noktada amaç bakımından da bir sınırlama söz konusu değildir. Bu nedenle TMK'nın 101. maddesinin üçüncü fikrasında yer alan "Cumhuriyet'in Anayasa ile belirlenen niteliklerine ve Anayasa'nın temel ilkelerine, hukuka, ahlâka, milli birliğe ve milli menfaatlere aykırı veya belli bir ırk ya da cemaat mensuplarını desteklemek amacıyla vakıf kurulamaz." şeklindeki yasak herkes gibi TSK mensupları için de geçerlidir. Yukarıda bu yasaklara dair genel olarak bazı eleştiriler dile getirmişti. TSK mensuplarının hakkın diğer özneleri bakımından bu haktan daha sınırlı yaralanabilmesi hukuken mümkün olduğu için amaç bakımından getirilen söz konusu yasakların uygulamada biraz daha geniş uygulanması olanaklı gözükmektedir.

\section{Genel Kolluk Mensupları}

Genel kolluk mensupları açısından değinilecek ilk düzenleme olan 3201 sayılı Emniyet Teşkilat Kanunu'nun Ek 11. maddesine göre teşkilat mensuplarının herhangi bir amaçla dernek kurucusu olması mümkün değildir. Bu konuda mutlak bir yasak söz konusudur. Yalnızca spor derneklerine üyelik serbest bırakılmışıtır. Bu tür bir yasağın örgütlenme özgürlüğüne uygun görülmesi mümkün gözükmemektedir. Vakıfların kuruluş amaçları bakımından ise TSK mensuplarından farklı olarak açık bir düzenleme vardır ve TMK hükümlerine göre kurulacak yeni vakıflar açısından kurucu olmak İçişleri Bakanlığının izniyle dahi olsa mümkündür ve kurucusu olunacak vakıflara ilişkin amaç bakımından bir sınırlama söz konusu değildir. Kanun'da amaç bakımından bir sınırlama olmasa da yukarıda TSK mensupları bakımından olduğu gibi, TMK'nın 101. maddesindeki yasaklanmış amaçlara ilişkin düzenleme Emniyet mensupları açısından da geçerlidir.

Öte yandan 7068 sayılı Kanun'un 8/6-gg maddesi vakıf kurmayı bir disiplin suçu olarak düzenlemiş ve bu fiile meslekten çıkarma cezası öngörmüştür. 3201 sayılı Kanun'un Ek 11. maddesi ile birlikte yorumlandığında söz konusu filin İçişleri Bakanlığı'nın izni olmaksızın vakıf kurmak olarak uygulanması gerekmektedir. Sahil Güvenlik Komutanlığı ile Jandarma Genel Komutanlığı mensupları açısından ise 
2692 say11 Kanun'un 21/a maddesi ile 2803 say1l Kanun'un 15/a maddesi disiplin işlerinin özel kanun hükümlerine göre yürütüleceğini düzenlemiş̦tir. Söz konusu özel kanun 7068 sayılı Kanun'dur ve bu Kanun'a göre her iki kurum mensuplarının dernek kurma ve vakıf kurma hakkı bu fiillere meslekten çıkarma cezası öngörüldüğü için bulunmamaktadır. Emniyet mensupları İçişleri Bakanlığı'nın izniyle vakıf kurucu olabilecekken diğer iki kurum mensuplarının hangi amaçla olursa olsun bu tür bir hakkı bulunmamaktadır. TSK ve genel kolluk mensuplarına ilişkin mevzuatın parçalı olması dernek ve vakıf kurucusu olma bakımından tam bir karmaşanın ortaya çıkmasına yol açmıştır.

\section{Diğer Kamu Görevlileri}

TSK ve genel kolluk mensupları dışında kalan kamu görevlileri açısından konuya ilişkin temel düzenleme 657 sayılı Devlet Memurları Kanunu'dur. Kanun'un 7. maddesinin ilk fikrası öncelikle herhangi bir siyasi parti, kişi veya zümrenin yararını veya zararını hedef tutan bir davranışta bulunmayı ve siyasi eylemde bulunmayı yasaklamıştır. Bu yasaklama 657 sayılı Kanun'a tabi kamu görevlilerinin siyasi amaçlı olarak dernek ve vakıf kurucusu olamayacağı anlamına gelmektedir. Yukarıda TSK mensupları açısından değinilen "siyasi” dernek ve vakıf kurma yasağına ilişkin eleştiriler burada da geçerlidir.

Kanun'un aynı maddesinin ikinci fikrasında ise Anayasa'ya ve kanunlara aykırı olan, memleketin bağımsızlığını ve bütünlüğünü bozan Türkiye Cumhuriyetinin güvenliğini tehlikeye düşüren herhangi bir faaliyette bulunan herhangi bir harekete, gruplaşmaya, teşekküle veya derneğe katılmak yasaklanmıştır. Madde metninde yer alan "teşekkül" ifadesinin vakıfları da kapsayacak biçimde diğer örgütlenmeleri içerdiği söylenebilir. Kanun'un 7. maddesinin her iki fikrasında kullanılan kavramlar oldukça muğlaktır ve yorum yoluyla kamu görevlilerinin dernek ve vakıf kurma haklarına örgütlenme özgürlüğüne aykırı sınırlamalar getirilmesine yol açabilecek nitelikte gözükmektedir.

\section{Kamu Görevlilerinin Dernek ve Vakıflara Üye Olma Hakkı}

\section{A. Genel Olarak Üyelik ve Buna Bağlı Diğer Haklar}

Örgütlere üye olma hakkı da örgütlenme özgürlüğünün ayrılmaz bir parçasıdır. Bir kişinin gerçek veya tüzel kişi ya da vatandaş veya yabancı olup olmadığına bakılmaksızın üye temelli bir örgüte üye olma hakkı söz konusudur. Bu konuda yapılacakyasaldüzenlemelerin ayrımcılıkiçermemesiveaşırı kısıtlamalargetirmemesi gerekmektedir. Hangi kişilerin üye temelli bir örgüte üye olup olamayacağı öncelikle ilgili örgütün kendisi tarafindan belirlenmelidir. ${ }^{160}$ Yasal düzenlemeler bir örgüte

$\overline{160 \mathrm{CM} / \operatorname{Rec}(2007) 14, \text { para } 22 .}$ 
üye olmuş kişinin kendi tüzüğüne aykırı bir şekilde üyelikten çıarılmasına karşı da güvence sağlamalıdır. Aynı şekilde güvence sağlanması gereken durumlardan birisi de bir örgüte üye olan kişinin üyeliği yüzünden herhangi bir yaptırımla karşılaşması olasılığıdır. Bu konuda belirli meslek grupları için sınırlama getirilmesi mümkündür ancak sınırlamaların belirli bir makam veya mesleğe özgülenmesi gerekmektedir. ${ }^{161}$

Örgütlenme özgürlüğü, örgüt kurma özgürlüğünün mantıksal ve doğal sonucu olan kurulu örgütlere üye olma hakkını da içermektedir. ${ }^{162}$ Hakkın bu boyutu da hem AİHS'nin 11. maddesi, hem de Anayasa'nın 33. maddesi ile koruma altına alınmıştır. AİHS'nin 11. maddesi "Herkes, (...) menfaatlerini korumak için (...) başkalarıla birlikte örgütlenme özgürlüğü hakkına sahiptir.” ve Anayasa'nın 33. maddesi “Herkes, önceden izin almaksızın dernek kurma ve bunlara üye olma ya da üyelikten çıkma hürriyetine sahiptir." diyerek derneklere ve vakıflara üyeliği güvence altına almıştır. $\mathrm{Bu}$ durum herkesin her istediği derneğe veya vakfa üye olabilmesi veya dernek ve vakıfların üyelik başvurusunda bulunan herkesi üye kaydetmek zorunluluğu altında oldukları anlamına gelmemektedir. ${ }^{163}$ Kural olarak herkesin herhangi bir derneğe üye olma hakkı şeklinde bir hak örgütlenme özgürlüğü kapsamında yer almamaktadır. $\mathrm{Bu}$ noktada örgütlenme özgürlüğünün öznesi olan örgütün özerkliği daha ağır basmaktadır. $\mathrm{Bu}$ noktada bir mesleğin yürütülebilmesi için bir derneğe üyeliğin zorunlu kılınmış olması ve ilgili derneğin kendi alanında fiilen tekelleşmesi ve kişinin keyfi olarak ve ayrımcılık oluşturacak biçimde bir derneğe alınmaması bu durumun istisnaları olarak kabul edilebilir. ${ }^{164}$

Dernekler bakımından TMK'nın özellikle 69/2 ve 70/2 maddeleri ile diğer maddelerinden derneklerde kurucu üye, asıl üye ve onursal üye biçiminde üç farklı üyelik biçimine yer verildiği görülmektedir. Kurucu üyeler ile kurucu olmayıp sonradan üye olan asıl üyeler arasında statü bakımından bir farklılık bulunmamaktadır. Onursal üyeler ise diğer üyelerden farklı bir statüdedirler. Buna göre aidat ödemek zorunda değildirler ve genel kurula katılabilmekle birlikte oy kullanma hakkı bulunmamaktadır. Onursal üyelerin üyelik statüsünün kazanılması ve kaybedilmesi bakımından diğer üyelerden bir farklılığı bulunmamaktadır. ${ }^{165}$ Kamu görevlileri ile ilgili aşağıda üzerinde durulacak kanunlara bakıldığında üyelik statüsü bakımından herhangi bir ayrıma gidilmediği ve üyeliğin her biçimini kapsayacak şekilde üyeliğe izin verildiği veya yasaklamaya gidildiği görülmektedir.

Vakıflar üye temelli örgütler olmadığı için bu bölümde özellikle dernekler üzerinde durulmuştur. Ancak AYM'nin 2008 yılında verdiği bir karar ile birlikte TMK'nın

\footnotetext{
$61 \mathrm{CM} / \operatorname{Rec}(2007) 14$, para 23-25.

162 Tomuschat, s. 498.

163 AïHK, Cheall v. the United Kingdom, Appl. No. 10550/83, 13.05.1985.

164 Serozan, Medeni Hukuk: Genel Bölüm, Kişiler Hukuku, s. 510; Dural; Öğüz, s. 293.

165 Dural; Öğüz, s. 291.
} 
"vakıflarda üyelik olmaz" ibaresine yer veren 101/3 maddesi iptal edilmiştir. AYM'ye göre Anayasa'nın 33. maddesinin son fikrasında yer alan söz konusu maddenin vakıflar hakkında da uygulanacağı hükmü dolayısıyla herkesin vakıflara üye olma özgürlüğü söz konusudur. Mahkeme iptal edilen hükmün bu özgürlüğü ortadan kaldırarak hakkın özüne dokunduğuna karar vermiştir. ${ }^{166}$

Bu karar sonrasında mevzuatta vakıflara üyeliğe ilişkin Vakıflar Genel Müdürlüğü’nün 2008/14 sayılı genelgesi ve aynı hükümlere yer vererek bu genelgeyi yürürlükten kaldıran 2016/1 sayıl genelgesi haricinde herhangi bir düzenleme yapılmamasına rağmen vakıflara üyeliğin fiilen yolu açılmıştır ve bu örgütlerce üye kaydı yapılması mümkündür. 2016/1 sayılı genelgeye göre vakıf senedinde üyelikle ilgili hüküm bulunan vakıflar üye alımı yapabileceklerdir ve vakıf senetlerinde 01.01.2002 tarihinden önce üyelikle ilgili hüküm bulunan ancak, TMK'nın "vakıflarda üyelik olmaz" hükmü nedeniyle senetlerinden üyelik hükümlerini çıkaran vakıflar, senet değişikliği yapmak suretiyle, konuya ilişkin mahkeme kararının kesinleşmesini müteakip üye alabileceklerdir. ${ }^{167}$

AYM kararıyla vakıflara üyelik yolu açılmış olsa da öğretide bu durum eleştirilmiş ve vakıf tüzel kişiliğinin üye kavramına yabancı olduğu, ${ }^{168}$ vakıfların üyeliğin vakıf kavramının özüyle bağdaşmadığı ve üyeliğin yolu açılsa dahi üyelerin derneklerde olduğu gibi üyelik haklarına sahip olamayacakları dile getirilmiştir. ${ }^{169}$ Vakıflarda üyeliğin olabileceği kabul edildiği takdirde kamu görevlileri bakımından mevzuatta herhangi bir özel sınırlamaya yer verilmediği görülmektedir.

Vakıflarda üyeliğe ilişkin açık bir düzenleme olmamakla birlikte 5737 sayılı Vakıflar Kanunu 9. maddesi ile vakıf yöneticisi olamayacak kişilere ilişkin bir hükme yer vermiştir. Öğretide vakıf üyeliği ile vakıfların organlarında üye olarak bulunmanın anlaşılması gerektiği belirtilmiştir. ${ }^{170}$ Maddenin ilk fikrasına göre, hırsızlık, nitelikli hırsızlık, yağma, nitelikli yağma, dolandırıcılık, nitelikli dolandırıcılık, zimmet, rüşvet, sahtecilik, hileli iflas, ihaleye fesat karıştırma, edimin ifasına fesat karıştırma, güveni kötüye kullanma, kaçakçılık suçları ile devletin güvenliğine karşı işlenen suçların birinden mahkûm olanlar vakıflarda yönetici olamazlar. Vakıflarda üyeliğin vakıf organlarına üyelik olarak anlaşılması durumunda, diğer bir deyişle yöneticilik söz konusu olduğunda ise, yöneticilik bakımından da kamu görevlilerine ilişkin bir yasak olmadığı görülmektedir. Bu nedenle aşağıda belirli kamu görevlileri açısından kendilerine ilişkin özel kanunlarda vakıf üyesi olup olmayacaklarına ilişkin de kısa tespitlerde bulunulmuş ve değerlendirmeler yapılmıştır.

\footnotetext{
166 AYM, E. 2005/14, K. 2008/92, 17.04.2008.

167 Vakıflar Genel Müdürlüğü, 2016/1 sayılı Genelge, 18.01.2016, s. 11, https://www.vgm.gov.tr/_layouts/download. aspx?SourceUrl=/Mevzuat $\% 2$ F08\%20\%2D\%20GENELGE\%2Fwebicerik325\%2Epdf (erişim:01.05.2018)

168 Dural; Öğüz, s. 363.

169 Serozan, s. 515-516.

170 Dural; Öğüz, s. 364.
} 
Üye olma hakkı birlikte gündeme gelen bir diğer konu üye olma zorunluluğudur. Örgütlenme özgürlüğü yalnızca üye olma hakkını değil üye olmama hakkını da içermektedir. ${ }^{171}$ Üye olmama hakkı örgütlenme özgürlüğünün negatif/olumsuz yönü olarak adlandırılabilir. ${ }^{172}$ Evrensel İnsan Hakları Beyannamesi’nin 20. maddesi negatif örgütlenme özgürlüğünü açıkça düzenlese de AİHS'de buna dair açık bir düzenlemeye yer verilmemiştir. ${ }^{173}$ Ancak AİHM içtihatlarına göre ne mevzuatın ${ }^{174}$ ne de toplu iş sözleşmesi ${ }^{175}$ gibi özel hukuk sözleşmeleri ile belirli örgütlere üyeliği zorunlu tutulması mümkün değildir. Özellikle kişinin kendi görüşlerine bütünüyle aykırı bir örgüte üye olmak zorunda bırakılması örgütlenme özgürlüğünün ihlaline yol açabilecektir. ${ }^{176} \mathrm{Bir}$ kişinin bir örgüte üye olmak zorunda bırakılması örgütlenme özgürlüğüne yönelik ciddi bir müdahaledir ve bu nedenle haklı bir nedenle gerekçelendirilmesi gerekmektedir.

$\mathrm{Bu}$ tür bir yasak yalnızca özel hukuk alanında kurulmuş örgütler bakımından geçerlidir. Üye olmama hakkının tek istisnası Anayasa'nın 135. maddesi gereği Türkiye'de örgütlenme özgürlüğünün öznesi olarak kabul edilip edilmeyeceği tartışmaya konu olan kamu kurumu niteliğindeki meslek kuruluşlarıdır. Bu kuruluşlar belirli bir mesleği düzenlemek üzere kanunla kurulmuşlardır ve üyelik kanunla zorunlu tutulmuştur. Dolayısıyla bu zorunluluğun bir örgüte üyelik zorunluluğu olarak kabul edilmesi mümkün değildir. Elbette bu durum yalnızca söz konusu örgütün özel hukuka tabi olmayan bir örgüt olması durumunda geçerlidir. Ancak kamu kurumu niteliğindeki meslek kuruluşları dışında herhangi bir özel hukuk tüzel kişisi sıfatı taşıyan dernek veya vakfa üyeliği zorunlu tutmak örgütlerin gönüllülük unsuru ile bağdaşmayacaktır. Öte yandan bir mesleği yürütmek için bir meslek örgütüne üyeliğin zorunlu tutulduğu durumda kişilerin yasayla kurulmuş meslek örgütü yanında özel hukuk alanında başka mesleki örgütlerde bir araya gelmelerinin yasaklanmaması gerekmektedir. ${ }^{177}$

Bir örgüte üye olmanın zorunlu tutulamaması yasağı bir örgüte bağış veya herhangi bir ad altında ödeme yapılmasının zorunlu tutulamamasını da içermektedir. Bu tür bir zorunluluk da örgütlenme özgürlügünün sınırlanması rejimine aykırı olduğu takdirde bu özgürlüğünün ihlalini oluşturacaktır. ${ }^{178}$ Anayasa'nın 33. maddesinde yer alan "Hiç kimse bir derneğe üye olmaya (...) zorlanamaz." hükmü ve TMK'nın 63. maddesindeki "Hiç kimse, bir derneğe üye olmaya (...) zorlanamaz" hükmü ile üye

\footnotetext{
171 Van Dijk; Van Hoof; Van Rijn; Zwaak, s. 833.

172 Ör. Harris; O’Boyle; Bates; Buckley, s. 744; Tomuschat, s. 502. Aldabak, s. 84; Ubillos, s. 418. Ayrica bkz, AİHM, Sigurdur A. Sigurjonsson v. Iceland, Appl. No. 16130/90, 30.06.1993; Chassagnou and Others v. France, Appl. Nos. 25088/94, 28331/95, 28443/95, 29.04.1999; Venice Commission, Opinion on the compatibility with universal human rights standards on the article 193-1 of the criminal code on the rights of non-registred associations of the Republic of Belarus, para 68.

173 Tomuschat, s. 502.

174 AïHM, Sigurdur A. Sigurjonsson v. Iceland, Appl. No. 16130/90, 30.06.1993, para. 36.

175 AïHM, Young, James and Webster v. the United Kingdom, Appl. No: 7601/76, 7806/77, 13.08.1981, para 55.

176 AİHM, Chassagnou and Others v. France, Appl. Nos: 25088/94 28331/95 28443/95, 29.04.1999, para 117.

177 Ubillos, s. 419.

178 AİHM, Vörour Olafsson v. Iceland, Appl. No. 200161/06, 27.04.2010.
} 
olmama hakkı güvence altına alınmıştır. Türk hukukunda herhangi bir örgüte üyeliği zorunlu tutan bir düzenleme bulunmadığı için örgütlenme özgürlüğünün bu boyutu ile ilgili bir sorun göze çarpmamaktadır.

\section{B. Kamu Görevlilerinin Derneklere ve Vakıflara Üyeliği}

\section{Türk Silahlı Kuvvetleri Mensupları}

Üye olma hakkı bakımından mevzuatta kamu görevlileri yine TSK mensupları, genel kolluk mensupları ve diğer kamu görevlileri bakımından bir dizi hüküm söz konusudur. 211 sayılı Türk Silahlı Kuvvetleri İç Hizmet Kanunu'nun 43/1 maddesi ile TSK mensuplarının siyasi dernekler üye olmaları açıkça yasaklanmıştır. Ancak Türk hukukunda "siyasi” dernek şeklinde bir kategori bulunmadığından ötürü bir derneğin "siyasi" dernek niteliğinde olup olmadığı Milli Savunma Bakanlığ1 tarafindan belirlenecektir. TSK mensuplarının "siyasi" olmayan derneklere de yine doğrudan üye olması mümkün değildir. TSK mensuplarının iki tür derneğe üye olması mümkün kılınmıştır. Bu kişilerin öncelikle Milli Savunma Bakanlığı tarafından adları yayınlanan derneklere üye olmaları mümkündür. ${ }^{179}$ TSK mensuplarının bunun haricinde spor kulüplerine "faal olmayan" üye biçiminde kaydolması mümkündür.

211 sayılı Kanun'da "faal olmayan" biçiminde bir ifade kullanılmış olsa da derneklerle ilgili mevzuata bakıldığında üyelik bakımından "faal olan" veya "faal olmayan" şeklinde ayrım bulunmamaktadır. Bu durumda iki farklı sonuca ulaşılması mümkündür. İlk olarak Kanun'da yer alan bu ifadenin spor kulüplerinin organlarında yer almama biçiminde yorumlanması mümkündür. İkinci olarak ise, TMK'nın 69, 70 ve 73. maddelerinde yer verilen "onursal üyelik" şeklinde bir statüye ya da buna benzer bir adla benzer bir üyelik statüsüne kendi tüzügü̈nde yer vermiş spor kulüpleri bakımından TSK mensuplarının bu tür bir statüde üye olabilecekleri biçiminde yorumlanması mümkündür. İkinci yorum benimsendiği takdirde TSK mensuplarının "onursal" ya da buna benzer ayrı bir statüye sahip üyelik biçimi öngörmeyen derneklere üye olamayacakları şeklinde bir sonuca ulaşılacaktır. Bu tür bir yaklaşım TSK mensuplarının spor kulüplerine üye olma hakkını daha da fazla sınırlama potansiyeline sahiptir. Bu nedenle Kanun'un 43/2 maddesindeki "faal olmayan üyelik" ifadesinin dernek organları olarak yorumlanması örgütlenme özgürlüğünden yararlanma olanağının genişletilmesi bakımından daha uygun gözükmektedir. TSK mensuplarının üye olabilecekleri bu iki tür dernekten birisine üye olması halinde ardından durumu en kısa zamanda Milli Savunma Bakanlı̆̆ı'na bildirmeleri gerekmektedir. TSK mensuplarının üye olabilecekleri üçüncü tür dernekler ise kendi kıta, karargah ve kurumları içinde kurulmuş olan amatör askeri spor kulüpleridir. $\mathrm{Bu}$ tür spor kulüplerinin kuruluşunda Genelkurmay Başkanlığı'nın izni gerekse de üyelik için bu tür bir izin gerekli değildir.

79 01.05.2018 tarihi itibariyle TSK mensuplarının hangi derneklere üye olabileceğine dair bir listeye Genelkurmay Başkanlığı (http://www.tsk.tr) veya Milli Savunma Bakanlığı'nın (http://www.msb.gov.tr) resmi internet sitelerinden ulaşılamamışı̧ır. 
Sonuç olarak TSK mensuplarının ancak önceden ismi ilan edilen derneklere ve spor kulüpleri ile kendi kıta, karargah ve kurumları içinde kurulmuş olan amatör askeri spor kulüplerine üye olması mümkündür. Bunlar dışındaki herhangi bir derneğe üye olunması durumunda idari yaptırım uygulanabilecektir. 6413 sayılı Türk Silahlı Kuvvetleri Disiplin Kanunu'nun 19/1-k maddesine göre barış zamanında derneklere ve spor kulüplerinin faal üyeliklerine izin almaksızın girildiği takdirde hizmet yerini terk etmeme cezası uygulanabilmektedir. Söz konusu fiil savaş zamanında işlendiği takdirde 477 sayılı Disiplin Mahkemeleri Kuruluşu, Yargılama Usulü ve Disiplin Suç ve Cezaları Hakkında Kanun'un 60. maddesine göre on günden iki aya kadar oda veya göz hapsi cezası verilmesi mümkündür.

TSK mensupları için vakıf üyesi olamayacaklarına dair açık bir hüküm bulunmadığından bu konuda bir yasaklamaya gidilmesi hukuken mümkün değildir. Ancak bir vakfa üyeliğin TSK tarafından siyasi faaliyet olarak değerlendirilmesi durumunda siyasi faaliyet yasağı dolayısıyla vakıf üyeliğine müdahalenin yolunun açılması mümkün gözükmektedir. Siyasi faaliyet için öngörülen yaptırım ise 6413 sayılı Kanun'un 20/1-d maddesine göre silahlı kuvvetlerden ayırma cezasıdır. Siyasi faaliyet niteliğinde olmayan vakıf üyelikleri bakımından ise bu tür bir yorumla yaptırım uygulanması Anayasa’ya aykırılık oluşturacaktır.

\section{Genel Kolluk Mensupları}

Emniyet görevlileri açısından yukarıda da belirtilen Emniyet Teşkilatı Kanunu Ek Madde 11'e göre Emniyet Genel Müdürlüğü mensuplarının spor dernekleri dışındaki derneklere üye olması yasaklanmıştır. $\mathrm{Bu}$ sınırlamaya uyulmaması durumunda 7068 sayılı Kanun'un 8/6-ff maddesine göre meslekten çıkarma cezası verilebilecektir. Anılan Kanun'un 9/1-a maddesine göre ise, üye olunan derneğin “Ülkenin bağımsızlığını zedelemeye, bütünlüğünü bozmaya ve milli güvenliği tehlikeye düşürmeye yönelik herhangi bir faaliyette bulunmak veya aynı nitelikte faaliyet gösteren" bir dernek olması durumunda verilecek ceza daha ağırlaşmakta ve devlet memurluğundan çıkarma cezası uygulanmaktadır. Görüldüğü üzere Emniyet mensuplarının spor dernekleri dışında başka bir derneğe üye olması halinde ilgili derneğin "Ülkenin bağımsızlığını zedelemeye, bütünlüğünü bozmaya ve milli güvenliği tehlikeye düşürmeye yönelik herhangi bir faaliyette bulunmak veya aynı nitelikte faaliyet gösteren" bir dernek olup olmadığına göre meslekten çıkarma veya devlet memurluğundan çıkarma cezası uygulanabilecektir. $\mathrm{Bu}$ noktada idarenin üye olunan derneğe yönelik tespiti verilecek cezanın belirlenmesinde büyük önem taşımaktadır. Söz konusu ifadenin oldukça muğlak bir ifade olmasından hareketle idareye oldukça geniş bir takdir yetkisi verildiği görülmektedir.

Geçmişte TSK mensubu olarak kabul edilen ve TSK mensuplarının tabi olduğu disiplin hükümlerine tabi olan Jandarma Genel Komutanlığı ve Sahil Güvenlik 
Komutanlığı personeli 7068 sayılı Kanun'un 1. maddesi ile Emniyet Genel Müdürlüğü personelinin tabi olduğu disiplin hükümlerine tabi olmuştur. Bu sebeple yukarıda Emniyet mensupları bakımından dernek üyesi olma bağlamında ortaya çıkan durum bu iki komutanlık mensupları için de geçerlidir.

Türk Silahlı Kuvvetleri mensupları için yasal bir sınırlama mevcut olmamakla birlikte Emniyet Teşkilatı Kanunu Ek Madde 11'e göre "Emniyet Teşkilatı mensupları ile çarş1 ve mahalle bekçilerinin 17/2/1926 tarihli ve 743 sayılı Türk Kanunu Medenisi kapsamındaki vakıfların... yönetim organlarında görev alabilmeleri Emniyet Genel Müdürünün teklifiyle İçişleri Bakanının iznine bağlıdır.” Bu sınırlamaya uyulmaması durumunda derneklerle ilgili olduğu gibi burada da disiplin cezası öngörülmüştür.

Yukarıda Türk Silahlı Kuvvetleri ve Emniyet mensupları açısından öngörülen dernek ve vakıf kurucusu olunmasını sınırlayan düzenlemeler bağlamında belirtilen durum üyelik ve yönetim organlarında bulunma için de geçerlidir. Her meslek grubu için örgütlenme özgürlüğü açısından ilgili meslek grubuna özgü bazı sınırlamalar öngörülebilecekse de bu şekilde özgürlüğü tamamen ortadan kaldıran düzenlemeler örgütlenme özgürlüğünün açıkça ihlalini oluşturmaktadır.

\section{Diğer Kamu Görevlileri}

Türk Silahlı Kuvvetleri ve Emniyet mensupları dışındaki kamu görevlileri için de bazı sınırlamalar söz konusudur. Bu durum örgütlenme özgürlüğünün ihlal edildiği anlamına gelmektedir. ${ }^{180}$ Devlet Memurları Kanunu'nun 7. maddesine göre "Devlet memurları her durumda Devletin menfaatlerini korumak mecburiyetindedirler. Türkiye Cumhuriyeti Anayasasına ve kanunlarına aykırı olan, memleketin bağımsızlığını ve bütünlüğünü bozan Türkiye Cumhuriyetinin güvenliğini tehlikeye düşüren herhangi bir faaliyette bulunamazlar. Aynı nitelikte faaliyet gösteren herhangi bir harekete, gruplaşmaya, teşekküle veya derneğe katılamazlar, bunlara yardım edemezler." Yukarıda dernek kuruculuğu ile ilgili getirilen eleştiriler üyelik bakımından da geçerlidir. "Türkiye Cumhuriyeti Anayasasına ve kanunlarına aykırı olan, memleketin bağımsızlığını ve bütünlüğünü bozan Türkiye Cumhuriyetinin güvenliğini tehlikeye düşüren herhangi bir faaliyette" bulunan derneklere üye olma yasağında hangi faaliyetlerin yasak kapsamında olduğu tamamen belirsizdir. $\mathrm{Bu}$ belirsizlik kamu görevlilerinin örgütlenme özgürlüğünün keyfi biçimde sınırlanmasına olanak tanımaktadır. Kamu görevlilerinin hangi tür derneklere üye olamayacaklarına dair açık bir yasal düzenleme yapılmalıdır. Madde metninde geçen "teşekkül” kelimesi vakıfları da kapsayacak biçimde ve bu nedenle vakıflara üyeliği de kapsayacak bir biçimde yorumlanması mümkün gözükmektedir.

$\overline{180}$ Human Rights Committee, Lebanon, A/52/40 vol. I (1997) 53, para. 357-358. 


\section{Değerlendirme}

Bir devlette örgütlerin kuruluşuna dair mevzuatın ve bunun yetkili makamlarca uygulanışı o devlette demokrasinin durumuna ilişkin belirleyici bir bir ölçüttür. ${ }^{181}$ Örgütlenme özgürlüğüne ilişkin mevzuatın hakkın özneleri bakımından zorlaştırıcı değil kolaylaştıııı, kısıtlayıcı değil özendirici olması gerekmektedir. Yukarıda kamu görevlilerinin dernek ve vakıflarda örgütlenme hakkı bakımından incelenen mevzuat kamu görevlilerinin örgütlenme özgürlügünü düzenlemekten öte çoğunlukla ortadan kaldırıldığını göstermektedir. Örgütlenme özgürlüğüne ilişkin oldukça eski bir bakış açısını yansitan bu durumun günümüz standartlarına uygun olduğunun kabulü mümkün değildir.

İkinci Dünya Savaşı sonrasında yaklaşık 70 yıl önce hazırlanan AİHS ve bir askeri darbe sonunda hazırlanan 1982 Anayasasının kamu görevlilerinin örgütlenme özgürlüğünün sınırlanabilmesine olanak sağlayan düzenlemelere yer vermesi anlaşılabilir bir durumdur. Ancak yukarıda üzerinde durulduğu üzere bu düzenlemeler devletler bakımından açık bir çek niteliğinde değildir. Günümüz koşullarında kamu görevlilerinin örgütlenme özgürlüğünü farklı biçimlerde kullanabilmesi söz konusu hakkın bir parçası haline gelmiştir.

Örgütlenme özgürlüğüne ilişkin negatif yükümlülükler AİHS'nin 11. maddesi182 ve Anayasa'nın 33, 51, 53, 54, 68 ve 69. maddelerinde zımni olarak düzenlenmiştir. AİHM'ye göre, AİHS'nin 11. maddesinin temel amac1 kamu otoritelerinin bireyin güvence altına alınan haklardan yararlanmasına yönelik keyfi müdahalelerine karşı korumaktır. ${ }^{183} \mathrm{AYM}$ de çeşitli bağlamlarda Anayasa'nın ilgili maddelerinin devlet için negatif yükümlülükler getirdiğini kabul etmiştir. ${ }^{184}$ AYM'ye göre, "Demokrasilerde vatandaşların bir araya gelerek ortak amaçları izleyebileceği örgütlerin varlığı sağlıklı bir toplumun önemli bir bileşenidir. Demokrasilerde böyle bir 'örgüt', devlet tarafından saygı gösterilmesi ve korunması gereken temel haklara sahiptir." ${ }^{185}$ Buna rağmen mevzuatın verili hali negatif yükümlülüklere aykırılık oluşturmaktadır.

Kamu görevlilerinin dernekler ve vakıflarda örgütlenmeye ilişkin mevzuatta kapsamlı değişikliklere gidilmesi gerektiği görülmektedir. $\mathrm{Bu}$ konuda dile getirilebilecek ilk eleştiri mevzuattaki katı kısıtlamalara ilişkindir. Kamu görevlileri bakımından her meslek grubu için örgütlenme özgürlüğü açısından ilgili meslek grubuna özgü bazı sınırlamalar öngörülebilecekse de özellikle TSK ve genel kolluk mensupları bu şekilde özgürlüğü tamamen ortadan kaldıran düzenlemeler örgütlenme özgürlüğünün açıkça ihlalini oluşturmaktadır. Üstelik mevzuata aykırı

\footnotetext{
181 AïHM, Sidiropoulos v. Greece, Appl. No: 26695/95, 10.07.1998, para 40.

182 AİHS için bkz, Tomuschat, s. 504-505.

183 AİHM, Sindicatul "Pastorul Cel Bun”v. Romania, Appl. No: 2330/09, 09.07.2013, para 131.

184 AYM, Tayfun Cengiz Kararl, B. No: 2013/8463, 18.09.2014, para 36; Abidin Aydın Tüfekçi Kararl, B. No: 2013/1315, 15.04.2015, para 35; İsmail Aslan ve Diğerleri Kararı, B. No: 2013/7197, 08.09.2015, para 42.

185 AYM, Tayfun Cengiz Kararl, B. No: 2013/8463, 18.09.2014, para 31; Abidin Aydın Tüfekçi Kararı, B. No: 2013/1315, 15.04.2015, para 30 .
} 
davranıldığ 1 durumda öngörülen yaptırımların sertliği örgütlenme özgürlüğünün başlı başına ihlaline yol açabilecek niteliktedir. Bu nedenle kanunlarda yer alan bu tür kısıtlamaların kapsamının daraltılması gerekmektedir.

İkinci olarak dile getirilebilecek bir eleştiri mevzuatta farklı kurumlara mensup kamu görevlileri için tutarsız bir biçimde farklı standartlar öngörülmüş olmasıdır. Farklı tarihlerde kabul edilmiş kanunlarda hakkın kapsamına ilişkin farklılıkların olması olağan olsa da bir haktan yararlanılmasına ilişkin yasal düzenlemelerin tutarlı olmasını beklemek de aynı şekilde olağandır.

Mevzuata ilişkin üçüncü bir eleştiri ise mevzuattaki yasal düzenlemelerin muğlaklığına ilişkindir. Örgütlenme özgürlüğüne yönelik anayasal koruma büyük ölçüde AİHS ve diğer uluslararası sözleşmelerle uyum taşımaktadır. Çalışma kapsamında dile getirilen uyumsuzlukların bir kısmının yorum yoluyla giderilmesi mümkündür. Ancak kamu görevlilerinin örgütlenme özgürlügünün tam anlamıla güvence altına alınması için mevzuatın yoruma ihtiyaç doğurmayacak biçimde açıkça kaleme alınması gerekmektedir. Bu durum hakkın kullanılmasına dair idarenin takdir yetkisinin sınırlanmasını ve keyfi müdahalelerinin önüne geçilmesinin sağlayacaktır. 


\section{Kaynakça}

\section{Kitaplar ve Makaleler}

Akbulut, Olgun; “Toplantı ve Örgütlenme Özgürlükleri”, İnsan Hakları Avrupa Sözleşmesi ve Anayasa: Anayasa Mahkemesine Bireysel Başvuru Kapsamında Bir İnceleme, Sibel İnceoğlu (ed.), Beta Yay., İstanbul, 2013.

Akın, İlhan; "Dernek Kurma Özgürlüğü”, İstanbul Üniversitesi Hukuk Fakültesi Mecmuası, Cilt 32, Say1 2-4, İstanbul, 1966.

Akipek, Jale G.; Akıntürk, Turgut; Ateş, Derya, Türk Medeni Hukuku, Birinci Cilt, Başlangıç Hükümleri, Kişiler Hukuku, Beta, İstanbul, 2015.

Aldabak, Ersel; “Avrupa İnsan Hakları Mahkemesi Kararlarında Örgütlenme Özgürlüğ̈̈”, Bülent Tanör'e Armă̆an, Yayıma Hazırlayan: Öget Öktem Tanör, Legal Yay., İstanbul, 2004.

Aslan, Metin; “Dernek Kurma Hürriyeti”, Galatasaray Üniversitesi Hukuk Fakültesi Dergisi, Say1 2010/1, İstanbul, 2011.

Dural, Mustafa; Öğüz, Tufan; Türk Özel Hukuku, Cilt II, Kişiler Hukuku, Filiz Kitabevi, İstanbul, 2013.

Esen, Selin; "Role of the European Court of Human Rights in the Turkish Constitutional Court's Rulings Regarding the Freedom of Association", Rule of Law, Human Rights and Judicial Control of Power, Ius Gentium: Comparative Perspectives on Law and Justice, R. Arnold and J.I. Martínez-Estay (eds.), Springer, 2017.

Gülmez, Mesut; "Dernek Özgürlüğü ve CinselYönelime Dayalı Ayrımcılık Sorunu: Lambdaistanbul Davası Kararları (Karar İncelemesi)", Çalışma ve Toplum Ekonomi ve Hukuk Dergisi, Sayı $22,2009$.

Harris, David; O'Boyle, Michael; Bates, Ed; Buckley, Carla; Harris, O'Boyle \& Warbrick, Law of the European Convention on Human Rights, Oxford University Press, Oxford, 2014.

Jayawickrama, Nihal; The Judicial Application of Human Rights Law: National, Regional and International Jurisprudence, Cambridge University Press, Cambridge, 2002.

Kılı̧̧oğlu, Ahmet; Medeni Hukuk: Temel Kavramlar, Başlangıç Hükümleri, Kişiler Hukuku, Turhan Kitabevi, Ankara, 2016

Kiai, Maina; Report of the Special Rapporteur on the rights to freedom of peaceful assembly and of association, A/HRC/20/27, 21.05.2012.

Oğuzman, M. Kemal; Seliçi, Özer; Oktay Özdemir, Saibe; Kişiler Hukuku (Gerçek ve Tüzel Kişiler), Filiz Kitabevi, İstanbul, 2013.

Rainey, Bernadete; Wicks, Elizabeth; Ovey, Clare; Jacobs, White, Ovey, The European Conventon on Human Rights, Oxford University Press, Oxford, 2014.

Serozan, Rona; Medeni Hukuk: Genel Bölüm, Kişiler Hukuku, Vedat Kitapçılık, İstanbul, 2013.

Serozan, Rona; “Türkiye'de Dernek ve Vakıf Kurmanın ve Yürütmenin Zorlukları”, Bülent Tanör'e Armağan, Yayıma hazırlayan: Öget Öktem Tanör, Legal Yay., İstanbul, 2004.

Serozan, Rona; Tüzel Kişiler: Özellikle Dernekler ve Vakıflar, Filiz Kitabevi, İstanbul, 1994.

Tomuschat, Christian; "Freedom of Association", The European System for the Protection of Human Rights, R. St. J. Macdonald; F. Matscher; H. Petzold (eds), Martinus Nijhoff Publishers, the Netherlands, 1993.

Ubillos, Juan Maria Bilbao; "Freedom of Assembly and Association (Art. 11 ECHR): Some Hesitations on a Path of Firm Protection", Europe of Rights: A Compendium of the European Convention of Human Rights, Pablo Santolaya Machetti; Javier Garcia Roca (Eds), Martinus Nijhoff, 2012. 
Uygun, Oktay; “Avrupa İnsan Hakları Sözleşmesi ve Türk Hukukunda İfade Özgürlüğünün Sinırları", Kamu Hukuku İncelemeleri, XII Levha Yay., İstanbul, 2011.

Van Dijk, P.; Van Hoof, G.J.H.; Van Rijn, Arjen; Zwaak, Leo; Theory and Practice of the European Convention on Human Rights, Intersentia, Antwerpen, Oxford, 2006.

Yokuş, Sevtap; "Dernek Özgürlüğü Çerçevesinde Türkiye'de Değişen Hukuksal Düzenlemeler”, Erdoğan Teziç'e Armağan, Galatasaray Üniversitesi Yayını, İstanbul, 2006.

Yücer, İpek; “Gerçek Kişilerin Vakıf Kurma Ehliyeti”, Prof. Dr. Sarper Süzek'e Armağan, Cilt III, Beta Yay., İstanbul, 2011.
Anayasa Mahkemesi Kararları
E. $1984 / 12$, K. 1985/6, 01.03.1985
E. $1985 / 7$, K. $1985 / 22,28.11 .1985$
E. $1995 / 39$, K. $1995 / 45,19.09 .1995$
E. $2005 / 14$, K. 2008/92, 17.04.2008
E. $2008 / 22$, K. $2010 / 82,17.06 .2010$
E. $2011 / 150$, K. $2013 / 30,14.02 .2013$
E. $2012 / 12$, K. $2013 / 7,10.01 .2013$
E. $2013 / 130$, K. $2014 / 18,29.01 .2014$
E. $2013 / 21$, K. $2013 / 57,10.04 .2013$
E. $2015 / 62$, K. $2015 / 84,30.09 .2015$

Abidin Aydın Tüfekçi Kararı, B. No: 2013/1315, 15.04.2015

Adalet Mehtap Buluryer Kararl, B. No. 2013/5447, 16.10.2014

Eğitim ve Bilim Emekçileri Sendikası ve Diğerleri Kararı, B. No: 2014/920, 25.05.2017

Fetullah Gülen Kararı, B. No: 2014/12225, 14.07.2015

Hint Aseel Hayvanları Koruma ve Geliştirme Derneği ve Hikmet Neğuç Kararı, B. No: 2014/4711, 22.02.2017

Hüseyin Demirdizen Kararl, B. No: 2014/11286, 21.09.2016

İsmail Aslan ve Diğerleri Kararı, B. No: 2013/7197, 08.09.2015

Sevim Akat Eşki Kararı, B. No: 2013/2187, 19.12.2013

Sinem Hun Kararl, B. No: 2013/5356, B. No: 08.05.2014

Tayfun Cengiz Kararı, B. No: 2013/8463, 18.09.2014

\section{Avrupa İnsan Hakları Mahkemesi Kararları}

ADEFDROMIL v. France, Appl. No. 32191/09, 02.10.2014

Albert and Le Compte v. Belgium, Appl. Nos. 7299/75 and 7496/76, 10.02.1983

Barthold v. Germany, Appl. No: 8734/79, 25.03.1985

Chassagnou and Others v. France, Appl. Nos: 25088/94 28331/95 28443/95, 29.04.1999

Church of Scientology Moscow v. Russia, Appl. No. 18147/02, 05.04.2007

Demir and Baykara v. Turkey, Appl. No. 34503/97, 12.11.2008

Féret v. Belgium, Appl. No: 15615/07, 16.07.2009

Gorzelik v. Poland, Appl. No. 44158/98, 17.02.2004 
Le Compte, Van Leuven and De Meyere v. Belgium, Appl. No: 6878/75, 7238/75, 23.06.1981

Les Authentiks and Supras Auteuil 91 v. France, Appl. No. 4696/11 and 4703/11, 27.10.2016

Matelly v. France, Appl. No. 10609/10, 02.10.2014

Radio France and Others v. France, Appl. No: 53984/00, 23.09.2003

Rekvenyi v. Hungary, Appl. No. 25390/94, 20.05.1999

Sidiropoulos v. Greece, Appl. No: 26695/95, 10.07.1998

Sigurdur Sigurjonsson v. Iceland, Appl. No: 16130/90, 30.06.1993

Sindicatul "Pastorul Cel Bun"v. Romania, Appl. No: 2330/09, 09.07.2013

Strzelecki v. Poland, Appl. No. 26648/03, 10.04.2012

Tebieti Mühafize Cemiyyeti and Israfilov v. Azerbaycan, Appl. No. 37083/03, 08.10.2009

The Moscow Branch of the Salvation Army v. Russia, Appl. No. 72881/01, 05.10.2006,

Trade Union of the Police in the Slovak Republic and Others v. Slovakia, Appl. No. 11828/08, 25.09.2012

Tüm Haber Sen and Çinar v. Turkey, Appl. No: 28602/95, 21.02.2006

Vogt v. Germany, Appl. No: 17851/91, 26.09.1995

Vona v. Hungary, Appl. No: 35943/10, 09.07.2013

Vörour Olafsson v. Iceland, Appl. No. 200161/06, 27.04.2010

Young, James and Webster v. the United Kingdom, Appl. No: 7601/76, 7806/77, 13.08.1981

Zhechev v. Bulgaria, Appl. No: 57045/00, 21.06.2007

\section{Diğer Kararlar ve Belgeler}

Danışma Meclisi Tutanak Dergisi, 8. Cilt, Birleşim 132, 21.08.1982

Council of Europe Parliamentary Assembly, Recommendation 1572 (2002), Right to association for members of the professional staff of the armed forces, http://www.assembly.coe.int/nw/xml/ XRef/Xref-XML2HTML-EN.asp?fileid=17031\&lang=en (erişim:01.05.2018)

Human Rights Committee, General Comment No. 34, Article 19: Freedoms of Opinion and Expression

Human Rights Committee, Kuwait, A/55/40 vol. I (2000) 65

Human Rights Committee, Lebanon, A/52/40 vol. I (1997) 53

Recommendation CM/Rec(2007)14 of the Committee of Ministers to member states on the legal status of non-governmental organisations in Europe, https://search.coe.int/cm/Pages/result details.aspx?ObjectID=09000016805d534d (erişim: 01.05.2018)

Türkiye Cumhuriyeti Anayasa Tasarısı ve Anayasa Komisyon Raporu, 1/463, S. Sayıs1 166'ya 1inci Ek, https://www.tbmm.gov.tr/tutanaklar/TUTANAK/DM_/d02/c007/ dm_02007120ss0166ek01.pdf (erişim:01.05.2018)

Vakıflar Genel Müdürlüğü, 2016/1 say1lı Genelge, 18.01.2016, https://www.vgm. gov.tr/_layouts/download.aspx?SourceUrl=/Mevzuat\%2F08\%20\%2 D\%20 GENELGE\%2Fwebicerik325\%2Epdf (erişim:01.05.2018)

Venice Commission, Opinion on the compatibility with human rights standards of the legislation on non-governmental organisations of the Republic of Azerbaijan, CDL-AD(2011)035

Venice Commission, Opinion on the compatibility with universal human rights standards on the article 193-1 of the criminal code on the rights of non-registred associations of the Republic of Belarus, CDL-AD(2011)036 